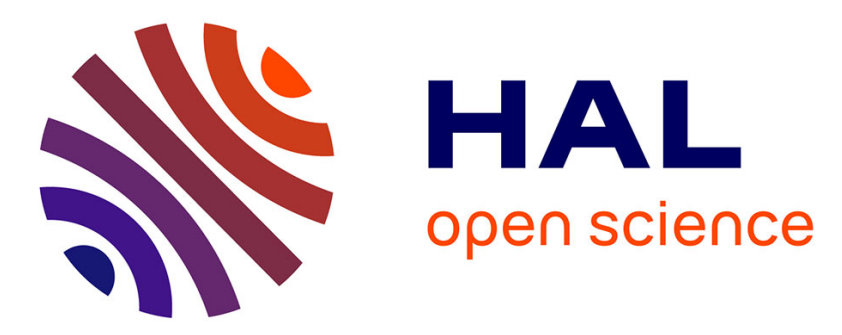

\title{
How did the ultramafic soils shape the flora of the New Caledonian hotspot?
}

\author{
Sandrine Isnard, Laurent L'Huillier, Frederic Rigault, Tanguy Jaffré
}

\section{To cite this version:}

Sandrine Isnard, Laurent L'Huillier, Frederic Rigault, Tanguy Jaffré. How did the ultramafic soils shape the flora of the New Caledonian hotspot?. Plant and Soil, 2016, 403 (1-2), pp.53-76. 10.1007/s11104-016-2910-5 . hal-01444630

\author{
HAL Id: hal-01444630 \\ https://hal.science/hal-01444630
}

Submitted on 21 Feb 2022

HAL is a multi-disciplinary open access archive for the deposit and dissemination of scientific research documents, whether they are published or not. The documents may come from teaching and research institutions in France or abroad, or from public or private research centers.
L'archive ouverte pluridisciplinaire HAL, est destinée au dépôt et à la diffusion de documents scientifiques de niveau recherche, publiés ou non, émanant des établissements d'enseignement et de recherche français ou étrangers, des laboratoires publics ou privés. 


\title{
How did the ultramafic soils shape the flora of the New Caledonian hotspot?
}

\author{
Sandrine Isnard • Laurent L'huillier • \\ Frédéric Rigault • Tanguy Jaffré
}

\begin{abstract}
Background New Caledonia is renowned as one of the world's most significant biodiversity hotpots. The nutrient-deficiency and cations imbalances of ultramafic soils, which cover a third of the island, harbor a disproportionally high proportion of the plant diversity and endemism of New Caledonia.

Scope This review explores how ultramafic soils have influenced the exceptional endemism and richness of New Caledonia trough the concomitant occurrences of habitat patchiness, climatic instability, environmental gradient, and edaphic heterogeneity of ultramafic soils. We focus on the unique 'maquis' vegetation where selective pressures by nutrient deficiency and trace element surplus are at their acme. We aim to synthesize our current understanding of diversification and speciation
\end{abstract}

of lineages that have been phylogenetically studied to date.

Conclusions Fragmentation of the peridotite mantle in isolated massifs, and as such spatial heterogeneity of ultramafic soils types, appear to promote plant endemism and speciation. Repeated independent dispersal events of pre-adapted species and persistence of paleoendemic lineages have contributed to the phylogenetic diversity and the endemism of the ultramafic flora. Finally, historical climatic instability has caused shifts of rain forest species in refugia thereby favoring the extension of maquis species.

Keywords Diversification · Endemism · Forests · Harsh edaphic conditions · Maquis · Nutritional strategies . Preadaptation $\cdot$ Species richness

\section{Introduction}

New Caledonia, located in the southwestern Pacific, is renowned for its exceptional flora (Morat et al. 2012; Schmid 1981; Thorne 1965; Virot 1956) and considered one of the world's most important biodiversity hotpots, as defined by Myers et al. (2000). The total vascular flora comprises $\sim 3370$ species of which more than $74 \%$ are endemic (Morat et al. 2012). The richness of the New Caledonian flora is attributed to the climatic, geological and topographical diversity of the archipelago (Jaffré 1993), combined with long-term isolation. The presence of old and early diverging lineages was previously considered as evidence of the Gondwanan origin 
of New Caledonia (e.g. Lowry II 1998; Morat 1993) with a flora dating back to the Cretaceous ( $85-65 \mathrm{Ma})$. However, recent geological studies (Pelletier 2006) and dated phylogenies (reviewed by Grandcolas et al. 2008; Murienne 2009), provided evidence for a more recent origin of the New Caledonia biota $\sim 37 \mathrm{Ma}$, consequently implying that most plant lineages colonized the island through long distance dispersal since the Eocene. The main island of New Caledonia (Grande Terre) experienced a submersion up to the late Eocene for a period of $\sim 20 \mathrm{Ma}$ (Pelletier 2006) and has probably been almost entirely covered by a slice of oceanic lithospheric mantle during its emersion, giving rise to the ultramafic bedrock that, after erosion and fragmentation, covers about one third of the surface area today (including the Belep and Pines islands totaling $\sim 5470 \mathrm{~km}^{2}$ ). Ultramafic outcrops are found from sea level to about $1600 \mathrm{~m}$ on Grande Terre. These outcrops include ultramafic massifs (Fig. 1), composed of peridotites mainly overlying serpentinite bedrock, which are known as "terrains miniers" (L'Huillier et al. 2010), and serpentinite outcrops occurring in the form of veins up to $10 \mathrm{~m}$ wide and several kilometers long within the volcano-sedimentary formations and at the base of ultramafic massifs on the western coast up to $400-450 \mathrm{~m}$. The ultramafic soils of New Caledonia are mineralogically, pedologically and chemically varied and supports diverse vegetation types (Fig. 2) and high levels of plant endemism (Jaffré 1980; Morat et al. 2012).

Edaphic endemism has been recognized as a key factor for stimulating plant diversity and endemism of several other global biodiversity hotspots, such as in California and the Mediterranean Region, the South African Cape and the Southwest Australian floras (Cowling and Lombard 2002; Hopper and Gioia 2004; Safford et al. 2005). In New Caledonia ultramafic soils have long been considered as the main causal factor of the plant richness and distinctiveness of the Island (Jaffré 1980, 1992; Pillon et al. 2010; Schmid 1982; Virot 1956). Although ultramafic plants in New Caledonia have been intensively studied, an integrated understanding, combining the current knowledge on floristic and soil diversity, habitat heterogeneity, and phylogenetic patterns of diversification and adaptation to a wide diversity of ultramafic soil properties, is lacking. Here we review the ways in which ultramafic soils have influenced patterns of plant diversity, distribution and endemism in New Caledonia. We use botanical information collected over the past decades, combined with recent insights from molecular studies that have produced robust phylogenetic hypotheses on patterns of plant diversification, thereby progressively filling the gaps in the evolutionary history of the New Caledonian flora. We consider the relative importance of factors such as habitat patchiness, climate, complex topography and the edaphic heterogeneity of ultramafic soils, on patterns of diversification and speciation of the (ultramafic) flora of New Caledonia.

\section{Methods and terminology}

The information contained in this article is based on an updated list of the ultramafic flora (which is available upon request). The list was first compiled from the 25 volumes of the Flora of New Caledonia (Aubréville et al. 1967-) and records from the herbaria of the IRD in Nouméa (NOU), the Muséum National d'Histoire Naturelle de Paris (P), and the Missouri Botanical Gardens (MO)). An extensive survey of recent literature, herbarium records and field observations was conducted to ensure the taxon listing was as complete as possible. The recently revised checklist of the New Caledonian flora "FLORICAL" (Morat et al. 2012; www.botanique.nc/herbier/florical) was used to update the taxonomy.

To score the affinity of taxa to ultramafic soils, we used species description or occurrence localities. We assigned the category "ultramafic-obligate" ("Uo") when habitat description or localities unambiguously states that a species is ultramafic- or serpentine-specialist. The category "ultramafic-facultative" ("Uf") was assigned when adjectives such as "often", "sometimes" or "usually" were added to the description of species' soil ecology. Finally, the category other "soil-obligate" ("Oo") was assigned to species that have not been observed on ultramafic soils. We then added to the list a number of taxa that we considered to be endemic or facultative to ultramafic soils but were not indicated as such by the current literature. The final list contains a total of 3313 documented native species, i.e. $98 \%$ of the total known flora.

Species were classified according to: (i) their status (endemic or native) and (ii) their distribution in the different vegetation types. For simplicity, the vegetation types have been treated as forest flora or non-forest flora. The ultramafic flora has been analysed in comparison to the flora occurring on all other soils. 

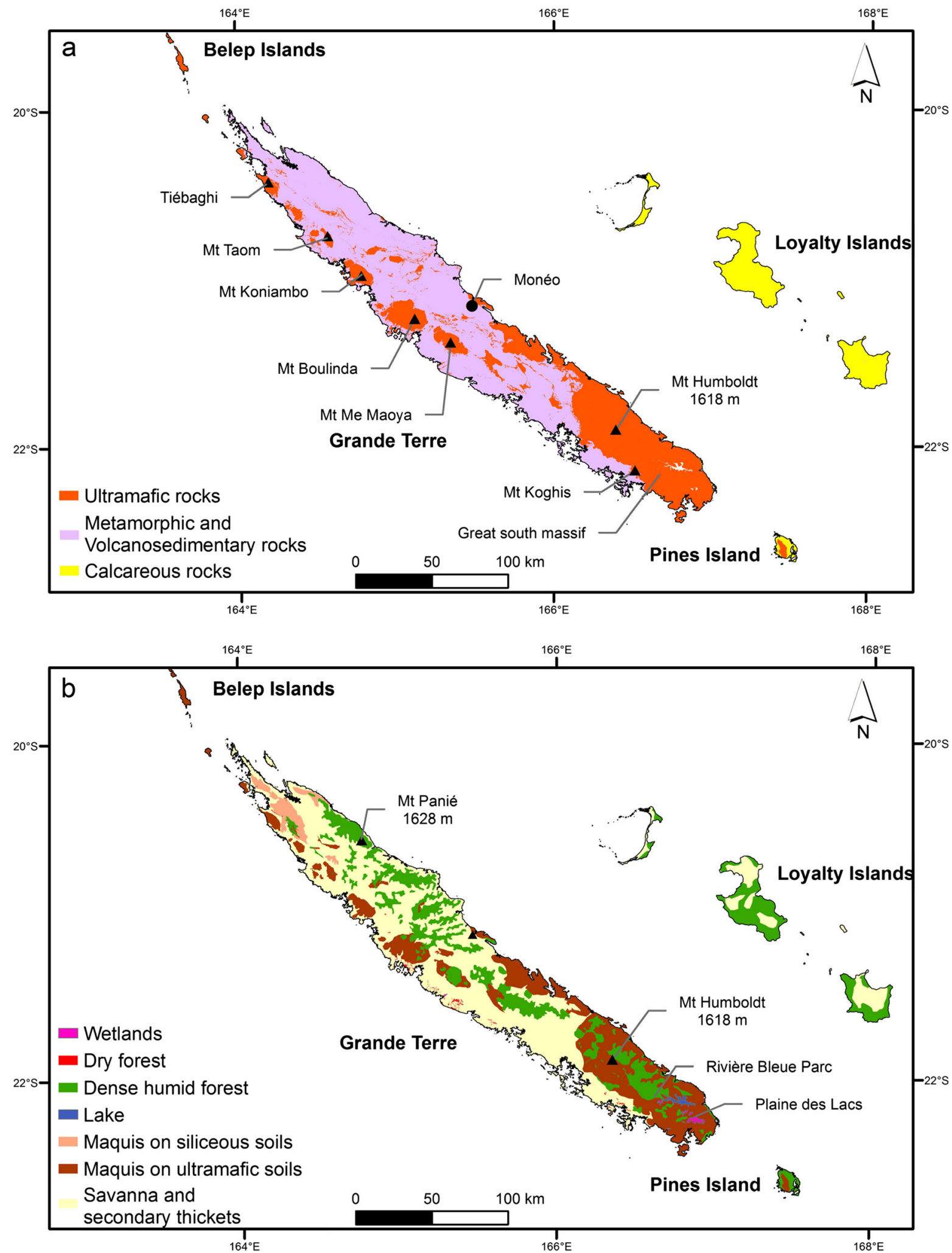

Fig. 1 Maps: a distribution of the main soil categories; $\mathbf{b}$ distribution of the main vegetation types 
Fig. 2 Main vegetation type on ultramafic soils: a Hydromorphic vegetation; $\mathbf{b}$ bushy maquis on serpentinite; c ligno-herbaceous maquis; $\mathbf{d}$ shrubby to bushy maquis; e shrubby to bushy altitudinal maquis; and $\mathbf{f}$ rain forest
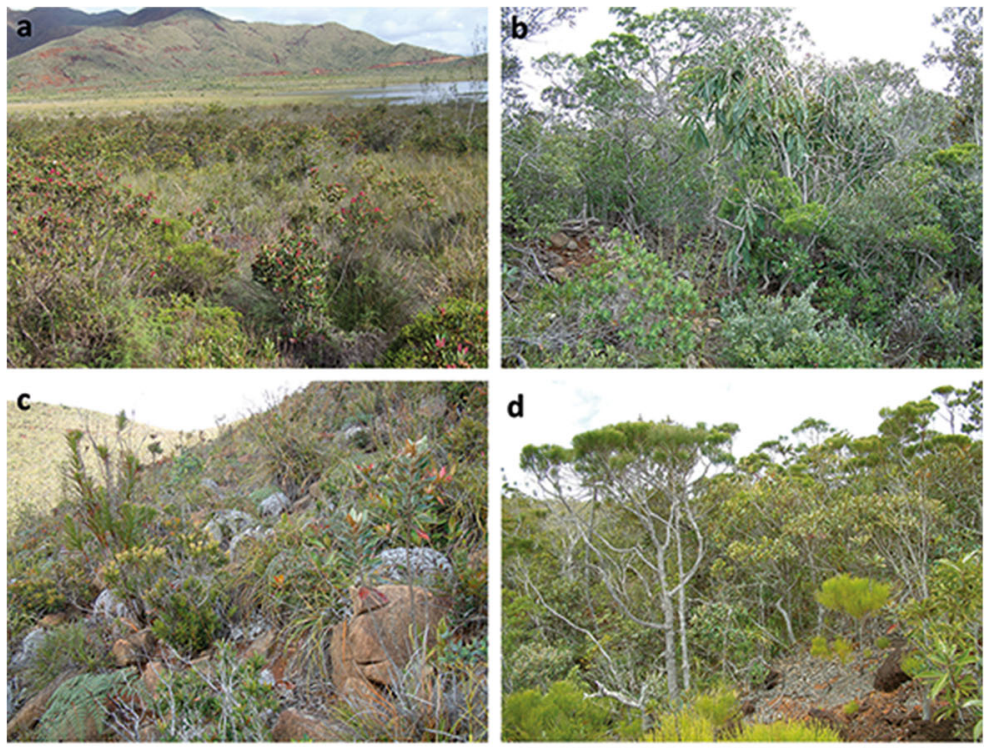

e
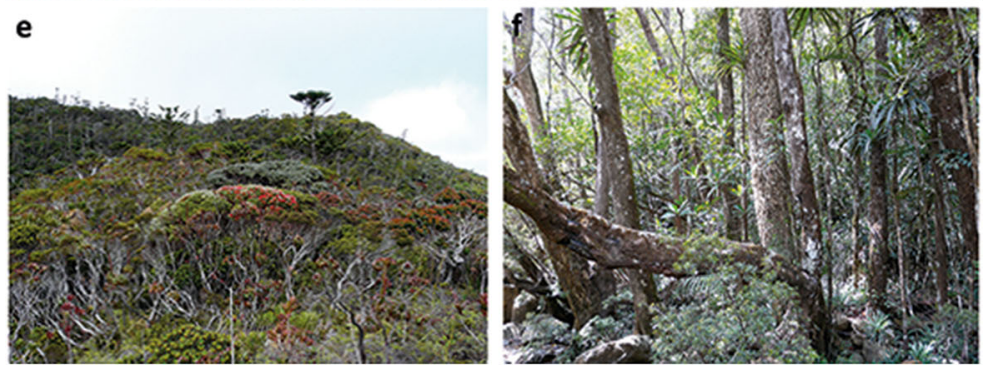

Characteristics of soils derived from ultramafic rocks in New Caledonia

All soils derived from ultramafic rocks in New Caledonia, as in other parts of the world (Bani et al. 2014; Brooks 1987; Cheng et al. 2011; Garnier et al. 2009; van der Ent et al. 2016; Walker 1954), are diverse but characterized by low fertility (low phosphorous (P), potassium $(\mathrm{K})$, and calcium $(\mathrm{Ca})$, high exchangeable magnesium/calcium $(\mathrm{Mg} / \mathrm{Ca})$ ratio and high concentration of the trace elements nickel (Ni), cobalt (Co), chromium $(\mathrm{Cr})$ and manganese $(\mathrm{Mn})$. Two main types of ultramafic soils have been described from New Caledonia: "Brown Hypermagnesian soils" (Jaffré and Latham 1974) also classified as Magnesic Cambisols (Fritsch 2012), and "Ferritic Ferralitic soils" (Latham 1975) also classified as Ferralsols (Fritsch 2012). Various processes resulting from the tectonic history, relief re-organization, and climatic changes (Chevillotte et al. 2006; Trescases 1975) have resulted in the formation of: (i) eroded Ferralsols; (ii) colluvial Ferralsols (iii) gravelly or indurated Ferralsols; and (iv) hydromorphic colluvio-alluvial Ferralsols (Table 1). The main chemical characteristics of soils derived from ultramafic rocks found in low sclerophyll evergreen scrublands (also called "maquis") are given in Table 1. Soils in rainforest differ in their thicker litter layer, higher rates of decomposition and higher nutrient concentrations. A comparison of the mineral composition of Ferralsols under adjacent maquis and rainforest is provided in Table 2.

The ultramafic soils of New Caledonia are immensely varied, as such represent a powerful useful models to study plant- soil relationships. Magnesic Cambisols on serpentinite, while representing only a small fraction of soils in New Caledonia, are equivalent to the "serpentine soils" which have been extensively studied (see Brady et al. 2005 for a review). Ferralsols are widespread in New Caledonia, and are more diversified than in many other regions due to their variation in depth (up to $30 \mathrm{~m}$ ), $\mathrm{pH}$ (3.25-6), concentrations in $\mathrm{Mg}$ and in available $\mathrm{Mn}$ and Ni (Becquer et al. 1995, 2002; L'Huillier 1994). Ferralsols can be assimilated within laterites but lack 
Table 1 Main chemical characteristics of soils derived from ultramafic rocks in the maquis of New Caledonia

\begin{tabular}{|c|c|c|c|c|c|}
\hline & \multirow{2}{*}{$\begin{array}{l}\text { Magnesic Cambisols } \\
(n=80)\end{array}$} & \multicolumn{4}{|l|}{ Ferralsols } \\
\hline & & $\begin{array}{l}\text { Eroded on slope } \\
(n=43) \\
\text { Mean (SD) }\end{array}$ & 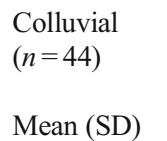 & $\begin{array}{l}\text { Plinthic (gravelly or indurated) } \\
(n=55) \\
\text { Mean (SD) }\end{array}$ & $\begin{array}{l}\text { Hydromorphic } \\
\text { colluvio-alluvial } \\
(n=4) \\
\text { Mean (SD) }\end{array}$ \\
\hline $\mathrm{pH}\left(\mathrm{H}_{2} 0\right)$ & $6.81(0.45)$ & $5.96(0.32)$ & $5.25(0.50)$ & $4.69(0.39)$ & $6.00(0.20)$ \\
\hline Org. Matter (\%) & $13.66(4.35)$ & $14.17(1.64)$ & $14.45(1.71)$ & $14,26(4,32)$ & - \\
\hline $\mathrm{N}(\mathrm{mg} / \mathrm{kg})$ & $1390(990)$ & $610(520)$ & $750(480)$ & $720(920)$ & $1100(300)$ \\
\hline $\mathrm{C} / \mathrm{N}$ & $14.40(3.41)$ & $16.65(7.93)$ & $18.37(6.57)$ & $21.81(10.47)$ & $12.90(4.42)$ \\
\hline \multicolumn{6}{|c|}{ Exch. cations $\left(\mathrm{cmol}_{\mathrm{c}} / \mathrm{kg}\right)$} \\
\hline $\mathrm{Ca}^{++}$ & $2.35(2.31)$ & $0.93(0.96)$ & $0.63(0.88)$ & $0.60(0.65)$ & $1.75(0.20)$ \\
\hline $\mathrm{Mg}^{++}$ & $33.50(15.00)$ & $2.04(1.54)$ & $0.70(1.11)$ & $0.52(0.52)$ & $9.62(2.61)$ \\
\hline $\mathrm{K}^{+}$ & $0.22(0.17)$ & $0.06(0.04)$ & $0.06(0.05)$ & $0.08(0.12)$ & $0.20(0.10)$ \\
\hline $\mathrm{Na}^{+}$ & $0.35(0.19)$ & $0.08(0.07)$ & $0.05(0.04)$ & $0.08(0.08)$ & $0.25(0.5)$ \\
\hline CEC & $40.90(18.20)$ & $8.15(6.15)$ & $6.03(4.69)$ & $7.65(6.48)$ & $24.40(7.00)$ \\
\hline \multicolumn{6}{|l|}{ Total elements } \\
\hline $\mathrm{P}(\mathrm{mg} / \mathrm{kg})$ & $108(89)$ & $83(47)$ & $151(48)$ & 185 (117) & - \\
\hline $\mathrm{SiO}_{2}(\%)$ & $30.2(9.4)$ & $5.2(6.4)$ & $2.81(2.30)$ & $1.37(2.40)$ & $5.90(1.80)$ \\
\hline $\mathrm{Al}(\%)$ & $1.84(1.19)$ & $2.63(1.13)$ & $3.43(1.13)$ & $3.00(1.43)$ & - \\
\hline $\mathrm{Fe}(\%)$ & $17.30(7.75)$ & $42.50(9.84)$ & $46.58(5.88)$ & $46.50(4.60)$ & $17.40(2.80)$ \\
\hline Mn (\%) & $0.43(0.38)$ & $0.47(0.28)$ & $0.56(0.30)$ & $0.46(0.36)$ & - \\
\hline $\mathrm{Ni}(\%)$ & $0.60(0.27)$ & $0.94(0.26)$ & $0.66(0.24)$ & $0.26(0.11)$ & $0.91(0.02)$ \\
\hline $\mathrm{Cr}(\%)$ & $1.20(1.37)$ & $2.11(1.46)$ & $2.51(1.45)$ & $4.24(2.82)$ & - \\
\hline Co $(\%)$ & $0.06(0.05)$ & $0.09(0.03)$ & $0.08(0.05)$ & $0.03(0.03)$ & - \\
\hline
\end{tabular}

Sampling depth: 0-20 cm. Organic Matter determined by loss on ignition. CEC: cation exchange capacity measured in $0.5 \mathrm{~m} \mathrm{NH} \mathrm{Nl}_{4}$. Data from Jaffré 1980; Jaffré and L'Huillier 2010; L'Huillier and Edighoffer 1996

kaolinite clays and consequently have a low ion exchange capacity.

"Non-ultramafic soils" are mostly associated with volcano-sedimentary rocks along the central chain of Grande Terre and metamorphic rocks in northeastern Grande Terre (Fritsch 2012). These soils generally have an acidic $\mathrm{pH}$ and contain high concentrations of aluminium (Latham et al. 1978). The western coast of Grande Terre is characterised by schist, limestone or basalt rocks with higher fertility than in other soils (Latham 1981).

\section{Contribution of the ultramafic flora to the diversity and endemism of the New Caledonian flora}

Plant species richness and endemism

The ultramafic and non-ultramafic floras of New Caledonia have an equivalent number of species, with $\sim 2100$ species found on either (Table 3). Thus, despite covering less than a $1 / 3$ of the surface area $\left(\sim 5500 \mathrm{~km}^{2}\right)$, ultramafic soils harbor a disproportionally high fraction of the total flora.

The ultramafic-obligate flora, represents over 1200 species and $\sim 50 \%$ of the endemic flora of New Caledonia, and makes a major contribution to distinctiveness of the Island (Table 3). The ultramafic obligate flora is remarkable by its very high endemism (96.7 \%), which is higher than the endemism of the non-ultramafic obligate flora (58\%). For comparison, Kinabalu Park in Sabah, renowned for its ultramafic vegetation, consists of over 1500 species on ultramafic soils (UM), with relatively few soil-endemics (van der Ent et al. 2014). Whereas the Californian flora consists of about 1410 species endemic to the state, only $\sim 180$ species are ultramafic-endemic (Safford et al. 2005). Further, the ultramafic outcrops in Western Australia harbours 1355 taxa of which only 14 are known to be soil-endemic 
Table 2 Comparison of ultramafic soil mineral properties according to vegetation type (from Read et al. 2006a)

\begin{tabular}{|c|c|c|c|c|}
\hline \multirow[t]{2}{*}{ Soil properties } & \multicolumn{2}{|c|}{ Forest $(n=3)$} & \multicolumn{2}{|c|}{ Maquis $(n=4)$} \\
\hline & Mean & SE & Mean & SE \\
\hline $\mathrm{pH}$ & 5.3 & 0.1 & 4.8 & 0.0 \\
\hline \multicolumn{5}{|l|}{ Total elements } \\
\hline $\mathrm{N}(\mathrm{mg} / \mathrm{kg})$ & 2390 & 100 & 1130 & 170 \\
\hline $\mathrm{C} / \mathrm{N}$ & 16.8 & 0.9 & 19,500 & 1100 \\
\hline $\mathrm{P}(\mathrm{mg} / \mathrm{kg})$ & 123 & 50 & 84 & 33 \\
\hline $\mathrm{K}(\mathrm{mg} / \mathrm{kg})$ & 147 & 65 & 72 & 23 \\
\hline $\mathrm{Mg}(\mathrm{mg} / \mathrm{kg})$ & 11,470 & 4840 & 5360 & 1480 \\
\hline $\mathrm{Ca}(\mathrm{mg} / \mathrm{kg})$ & 700 & 225 & 92 & 15 \\
\hline $\mathrm{Fe}(\mathrm{mg} / \mathrm{kg})$ & 396,000 & 6300 & 435,000 & 37,000 \\
\hline $\mathrm{Cr}(\mathrm{mg} / \mathrm{kg})$ & 91,400 & 46,900 & 61,900 & 17,500 \\
\hline Ni (mg/kg) & 5200 & 1690 & 4780 & 920 \\
\hline $\mathrm{Al}(\mathrm{mg} / \mathrm{kg})$ & 37,200 & 12,600 & 37,100 & 8400 \\
\hline \multicolumn{5}{|c|}{ Extractable elements } \\
\hline $\mathrm{P}\left(\mu \mathrm{g} \mathrm{g}^{-1}\right)$ & 0.9 & 0.3 & 0.4 & 0.1 \\
\hline $\mathrm{K}\left(\mathrm{cmol}_{\mathrm{C}} / \mathrm{kg}\right)$ & 0.38 & 0.07 & 0.26 & 0.07 \\
\hline $\mathrm{Mg}\left(\mathrm{cmol}_{\mathrm{C}} / \mathrm{kg}\right)$ & 2.72 & 0.79 & 0.29 & 0.10 \\
\hline $\mathrm{Ca}\left(\mathrm{cmol}_{\mathrm{c}} / \mathrm{kg}\right)$ & 1.85 & 0.41 & 0.22 & 0.06 \\
\hline
\end{tabular}

Sampling depth: 0-10 cm

(van der Ent et al. 2015a). The Queensland ultramafic flora is comprised of 553 species, of which only 19 are soil-endemics (Batianoff and Singh 2001). Finally, in New Zeeland, ultramafic outcrops host 34 soil-endemic taxa from a flora consisting of 2066 species (Lee 1992).

There is a strong disparity in ultramafic obligate endemism and species richness between lineages in New
Caledonia (Table 4). The most endemism-rich families are the Myrtaceae (112 ultramafic obligate species) and the Rubiaceae (100 ultramafic obligate species), which are also the families with the greatest number of species occurring in New Caledonia. In contrast, the Pteridophytes and Monocots make a low contribution to the ultramafic obligate flora (Table 4). Both groups are mainly represented by epiphytes and are therefore not directly associated with soils. Pteridophytes comprise about $40 \%$ of epiphytic species, while Orchidaceae, the second largest family in New Caledonia (42\% of monocot), consists of about $45 \%$ of epiphytes.

Most of the large families in the New Caledonian flora (i.e. those with at least 15 species) have a higher fraction of their species restricted to ultramafic soils (Fig. 3). The strong floristic affinities of New Caledonia with Australia is illustrated by families such as the Dilleniaceae, Ericaceae and Proteaceae (Morat et al. 1994; van der Ent et al. 2015a). Only 7 of the largest eudicots families of New Caledonia have a larger fraction of species occurring on other soils (Fig. 3).

Eudicot ultramafic obligate species are almost all endemic (99.3\%). Conversely, the four eudicot families with the highest proportion of obligate species on other soils have a relatively low level of endemism: Asteraceae (28.6\%), Moraceae (69\%), Malvaceae (59.6\%) and Fabaceae (62.1\%) (Morat et al. 2012). These families consist of a large number of ruderal, coastal or early successional species. The Asteraceae, which is among the under-represented families in New Caledonia (Pillon et al. 2010), is the most important family of serpentine endemic plants in California (Safford et al. 2005) and the

Table 3 Endemicity and number of species, genera and families in the different substrate-related floras

\begin{tabular}{|c|c|c|c|c|c|c|c|c|}
\hline & & \multirow[t]{3}{*}{ Total* } & \multirow{2}{*}{\multicolumn{2}{|c|}{$\frac{\text { UM Flora }}{\text { Uo }}$}} & \multicolumn{4}{|c|}{ Non-UM Flora } \\
\hline & & & & & \multicolumn{2}{|l|}{ Uf } & \multicolumn{2}{|l|}{ Oo } \\
\hline & & & No. & $\%$ & No. & $\%$ & No. & $\%$ \\
\hline \multirow[t]{2}{*}{ Species } & Total & 3309 & 1218 & 36.8 & 877 & 26.5 & 1214 & 36.7 \\
\hline & Endemic & 2492 & 1178 & $96.7(47.3)$ & 610 & $69.6(24.5)$ & 704 & $58(28.3)$ \\
\hline \multirow[t]{2}{*}{ Genera } & Total & 795 & 72 & 9.1 & 426 & 53.6 & 297 & 37.4 \\
\hline & Endemic & 97 & 36 & $50(37.1)$ & 55 & $12.9(56.7)$ & 6 & $2(6.2)$ \\
\hline \multirow[t]{2}{*}{ Families } & Total & 193 & 8 & 4.1 & 137 & 71 & 48 & 24.9 \\
\hline & Endemic & 3 & 0 & 0 & 2 & 1.5 & 1 & 2.1 \\
\hline
\end{tabular}

Numbers in brackets are the percentage of endemic species of the total flora

Uo ultramafic-obligate; $U f$ ultramafic-facultative; Oo other substrate-obligate

* documented species 
Table 4 Endemicity and number of species in the different substrate-related floras

\begin{tabular}{|c|c|c|c|c|c|c|c|c|}
\hline & & \multirow[t]{3}{*}{ Total* } & \multirow{2}{*}{\multicolumn{2}{|c|}{$\frac{\text { UM Flora }}{\text { Uo }}$}} & \multicolumn{4}{|c|}{ Non-UM Flora } \\
\hline & & & & & \multicolumn{2}{|l|}{ Uf } & \multicolumn{2}{|l|}{ Oo } \\
\hline & & & No. & $\%$ & No. & $\%$ & No. & $\%$ \\
\hline \multirow[t]{2}{*}{ Ferns and Lycophytes } & Total & 256 & 36 & 14.1 & 128 & 50 & 92 & 35.9 \\
\hline & Endemic & 99 & 22 & 61.1 & 46 & 35.9 & 31 & 33.7 \\
\hline \multirow[t]{2}{*}{ Monocots } & Total & 546 & 131 & 24 & 205 & 37.5 & 210 & 38.5 \\
\hline & Endemic & 260 & 117 & 89.3 & 88 & 42.9 & 55 & 26.2 \\
\hline \multirow[t]{2}{*}{ Gymnosperms } & Total & 46 & 29 & 63 & 14 & 30.4 & 3 & 6.5 \\
\hline & Endemic & 45 & 29 & 100 & 14 & 100 & 2 & 66.7 \\
\hline \multirow[t]{2}{*}{ Basal angiosperms } & Total & 111 & 39 & 35.1 & 39 & 35.1 & 33 & 29.7 \\
\hline & Endemic & 100 & 37 & 94.9 & 35 & 89.7 & 28 & 84.8 \\
\hline \multirow[t]{2}{*}{ Eudicots } & Total & 2354 & 979 & 41.6 & 494 & 21 & 881 & 37.4 \\
\hline & Endemic & 1987 & 972 & 99.3 & 427 & 86.4 & 588 & 66.7 \\
\hline
\end{tabular}

Uo ultramafic-obligate; $U f$ ultramafic-facultative; $O o$ other substrate-obligate

* documented species

largest family in the (non-ultramafic) South African Cape flora (Cowling and Holmes 1992). It thus remains unclear whether ecological filtering of ultramafic soils is a major factor in explaining the underrepresentation of Asteraceae in the New Caledonian flora as suggested by Pillon et al. (2010). The subtropical climate could also constitute a major barrier to the diversification of Asteraceae in New Caledonia.

Despite a roughly similar number of species on ultramafic and non-ultramafic soils, the ultramafic-obligate flora is contained in a smaller number of families and genera. The distinction of floras at the generic and family levels is essentially marked by the lack of many genera and families on ultramafic soils (Table 3). Thus despite high species richness, the phylogenetic diversity of the ultramafic-obligate flora appears to be relatively low. Among the 795 genera of the New Caledonia flora, only a small proportion of them (72 genera, $\sim 9 \%$ ) have all their species exclusively found on ultramafic soils. About a third of these genera have a wide geographical distribution (data not shown), which attests to the pivotal role played by the soil in their distribution. Endemicity at the generic level is remarkable for the ultramafic obligate flora since 36 out of the 97 endemic genera of the New Caledonian flora have their species restricted/obligate to ultramafic soils, while only 6 genera are restricted to nonultramafic soils (Table 3). Endemic genera associated with ultramafic soils represent more than $37 \%$ of all the endemic genera of New Caledonia, a percentage similar to Cuba (32-33\% of endemic genera) (Borhidi 1991; Iturralde 2001). This high generic endemicity confirms the selective power of ultramafic soils that strongly favor endemism, but not necessary species richness since endemic ultramafic-obligate genera are essentially species-poor in New Caledonia. This low infra-generic endemic diversity is not a specificity of the ultramafic flora, since among the six endemic genera found exclusively on non-ultramafic soils, four are mono-specific and two genera have only two species each.

About $75 \%$ of the families have at least one representative on ultramafic soils but only eight of them are restricted/obligate to ultramafic soils (Table 3). None of the three families endemic to New Caledonia are exclusively found on ultramafic soils, while one of them (Amborellaceae) is restricted to non-ultramafic soils (Table 3). There is a striking lack of New Caledonian mono-specific families belonging to the Trimeniaceae and Amborellaceae on ultramafic soils, while these species are relatively widely distributed in New Caledonia.

Hence, the ultramafic obligate flora has a higher level of endemism at both the species and generic level compared to the flora associated with nonultramafic soils. The majority of the genera endemic to New Caledonia are soil-facultative which confirms that the ultramafic flora contributes to the endemicity and originality of the flora of New Caledonia, and that the juxtaposition of different substrates is an important source of diversity. 


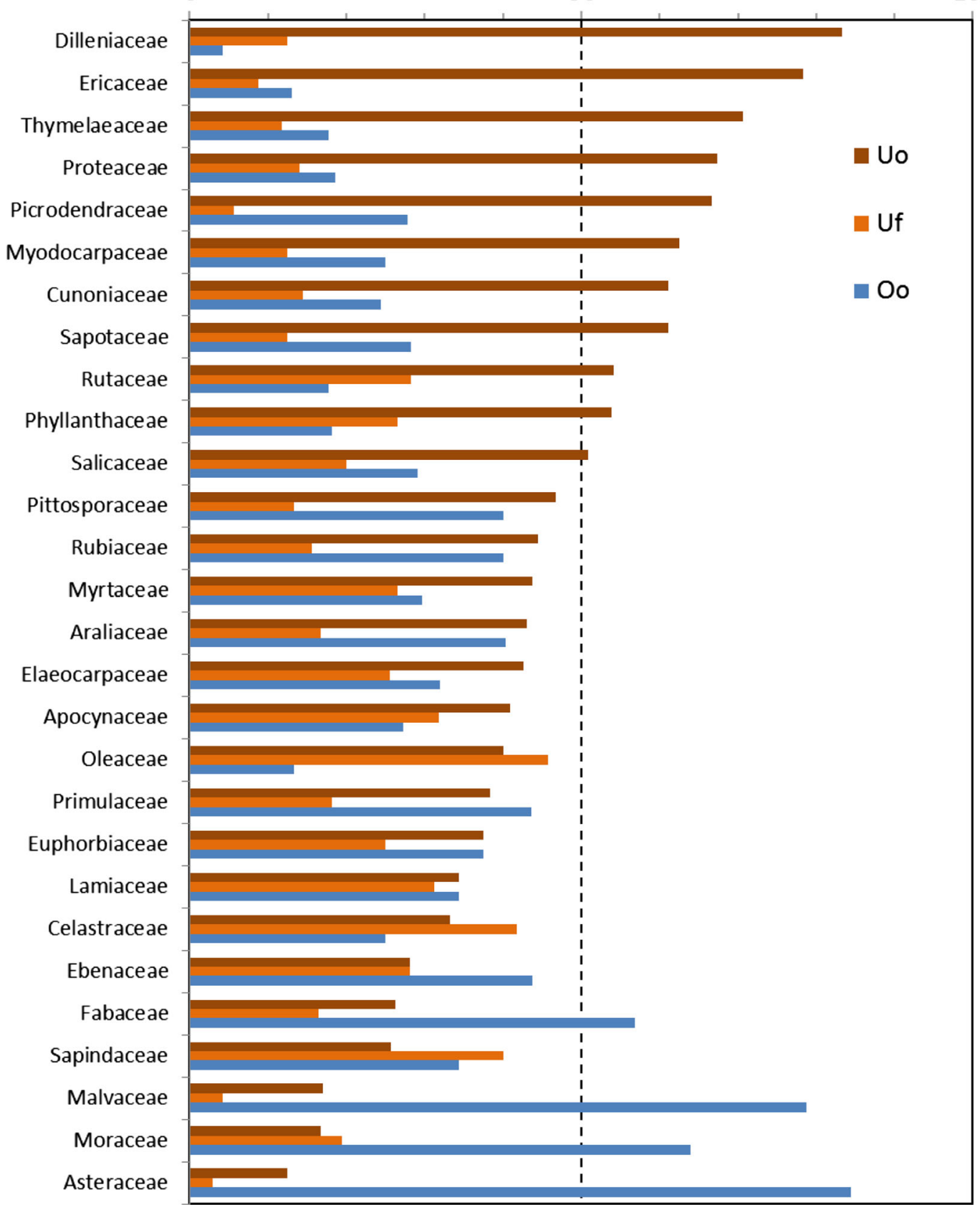

Fig. 3 Proportion of substrate-related species for eudicot families with at least 15 species in the native flora of New Caledonia. Abbreviations: Uo Ultramafic-obligate; Uf ultramafic-facultative; Oo other substrate-obligate

Vegetation of ultramafic soils versus other soils

As elsewhere, the vegetation on ultramafic outcrops is discernable from the vegetation on other substrates by its distinctiveness and physiognomy (Fig. 2), as illustrated by the maquis in New Caledonia that contrasts with savannas and thickets constituting the secondary vegetation on non-ultramafic soils. However, the maquis of New Caledonia are floristically and physiognomically varied, and range from shrubby, evergreen, sclerophyllous to cyperoid vegetation depending on soil properties (Jaffré 1980; van der Ent et al. 2015a). Three 
main maquis types found in New Caledonia are: (i) "bushy maquis", (ii) "shrubby to bushy maquis"; (iii) "ligno-herbaceous maquis" (Fig. 2; Table 5). These vegetation types mainly result from the destruction of the initial forests by fire, although some subalpine maquis might have existed at higher elevation on the most exposed summits (Nasi et al. 2002) or at lower elevation on the dry western coast (Morat et al. 1986). Thus, most maquis is composed of fire-adapted species (Jaffré and L'Huillier 2010; Jaffré et al. 1998b; McCoy et al. 1999). The maquis also includes (i) heliophilous hydromorphic vegetation characterized by a shrubby layer along riverbanks with a dense herbaceous layer (Jaffré and L'Huillier 2010); (ii) the vegetation growing on serpentinite veins, on Magnesic Cambisols, included within metamorphic or volcano-sedimentary soils, (Jaffré 1980); (iii) altitudinal maquis composed of mountain species, sometimes dominated by Araucaria spp. (e.g. A. humboldtensis). This maquis, mainly found on summits, can developed into forest once protected from wind or fire (Jaffré 1980; Nasi et al. 2002).

The maquis contains at least 840 species restricted to this vegetation type (Fig. 4). The richness of the maquis is remarkable considering the relatively small area covered by this vegetation (4300-4400 $\mathrm{km}^{2}$ ) compared to the total area covered by other non-forest vegetation on non-ultramafic soils $\left(\sim 6000-7000 \mathrm{~km}^{2}\right)$ (Jaffré et al. 2009) (Fig. 1b). The maquis is particularly remarkable by its very high level of endemism (96.9 \%) (Fig. 4). The families with a majority of ultramafic endemic species occur in the maquis (e.g. Dilleniaceae, Ericaceae, Proteaceae, Cunoniaceae, Myrtaceae) (Fig. 3). The non-forest vegetation on non-ultramafic soils is mainly covered by savannas or secondary thickets, which are generally species-poor. The nonforest flora exclusive of non-ultramafic is also relatively poor and consists of much fewer endemic species (14.4\% endemism). Most species occur in secondary

Table 5 Vegetation types on ultramafic and non-ultramafic rocks and their associated biotic and abiotic features

\begin{tabular}{|c|c|c|c|c|c|}
\hline & Surface $\left(\mathrm{km}^{2}\right)$ & Soil type & Altitude & $\begin{array}{l}\text { Woody } \\
\text { stratum }\end{array}$ & $\begin{array}{l}\text { Herbaceous stratum } \\
(\text { Cyperaceae }(\mathrm{C}) \text { or } \\
\text { Poaceae }(\mathrm{P}))\end{array}$ \\
\hline Ultramafic rocks & $5600-5700$ & & $0-1816 \mathrm{~m}$ & & \\
\hline Rain forest & $1100-1200$ & Magnesic Cambisols, Ferralsols & $>10 \mathrm{~m}$ & $20-30 \mathrm{~m}$ & $\mathrm{C}, \mathrm{P},<10 \%$ \\
\hline Maquis & 4500 & & & & \\
\hline Bushy & & Magnesic Cambisols & $<400 \mathrm{~m}$ & $1-6 \mathrm{~m}$ & C, $20-40 \%$ \\
\hline Shrubby to bushy & & Plinthic $(\mathrm{F})$ & $\begin{array}{r}0-1816 \mathrm{~m}(\mathrm{most} \\
\text { often }>200 \mathrm{~m})\end{array}$ & $50 \mathrm{~cm}-5 \mathrm{~m}$ & $\mathrm{C},<15 \%$ \\
\hline Ligno-herbaceous & & $\begin{array}{c}\text { Magnesic Cambisols } \\
\text { (serpentinite vein) }\end{array}$ & $<600 \mathrm{~m}$ & $1-6 \mathrm{~m}$ & C, P, 50-100\% \\
\hline \multirow[t]{3}{*}{ Ligno-herbaceous } & & Eroded $(\mathrm{F})$ & $0-1816 \mathrm{~m}$ & $20 \mathrm{~cm}-80 \mathrm{~cm}$ & $\mathrm{C},>50 \%$ \\
\hline & & Colluvial (F) & $0-1800 \mathrm{~m}$ & $1-5 \mathrm{~m}$ & $\mathrm{C},>50 \%$ \\
\hline & & Hydromorphic (F) & $200-280 \mathrm{~m}$ & $120-\mathrm{cm}-2 \mathrm{~m}$ & $\mathrm{C},>50 \%$ \\
\hline Maquis passing forest ${ }^{\mathrm{a}}$ & & All non-hydromorphic soils & $10-1800 \mathrm{~m}$ & $5-7 \mathrm{~m}$ & $\mathrm{C},<50 \%$ \\
\hline Non-ultramafic rocks & & & $0-1816 \mathrm{~m}$ & & \\
\hline Rain forest & $1800(+900)$ & $\begin{array}{l}\text { metamorphic rocks } \\
\left(+ \text { calcareous rocks }^{\mathrm{b}}\right)\end{array}$ & $>300-400 \mathrm{~m}$ & $20-30 \mathrm{~m}$ & $\mathrm{P},<10 \%$ \\
\hline $\begin{array}{l}\text { Sclerophylous and } \\
\text { mesic forest }\end{array}$ & 450 & Sedimentary rocks & $<300 \mathrm{~m}$ & $8-15 \mathrm{~m}$ & $\mathrm{C}, \mathrm{P},<20 \%$ \\
\hline Savanna and thicket & 6000 & $\begin{array}{l}\text { Metamorphic, calcareous, } \\
\text { volcano-sedimentary rocks }\end{array}$ & $<600 \mathrm{~m}$ & $6 \mathrm{~m}$ & $\begin{array}{l}\mathrm{P}, 100 \%, 10-60 \% \\
\quad \text { (thicket) }\end{array}$ \\
\hline Wetland & 1000 & Freshwater and salty & $<270 \mathrm{~m}$ & $0-8 \mathrm{~m}$ & - \\
\hline Siliceous "maquis" & 600 & Siliceous or acid soils, mica-schist & $10-1000 \mathrm{~m}$ & $5-6 \mathrm{~m}$ & $\mathrm{C}, \mathrm{P},<30 \%$ \\
\hline
\end{tabular}

Data from Jaffré 1980; Jaffré and L'Huillier 2010; Jaffré et al. 2009

$F$ ferralsols

a "Maquis paraforestier" that forms an interface with a strict maquis and comprises several distinctive species

${ }^{\mathrm{b}}$ Principally on the Loyalty Islands 


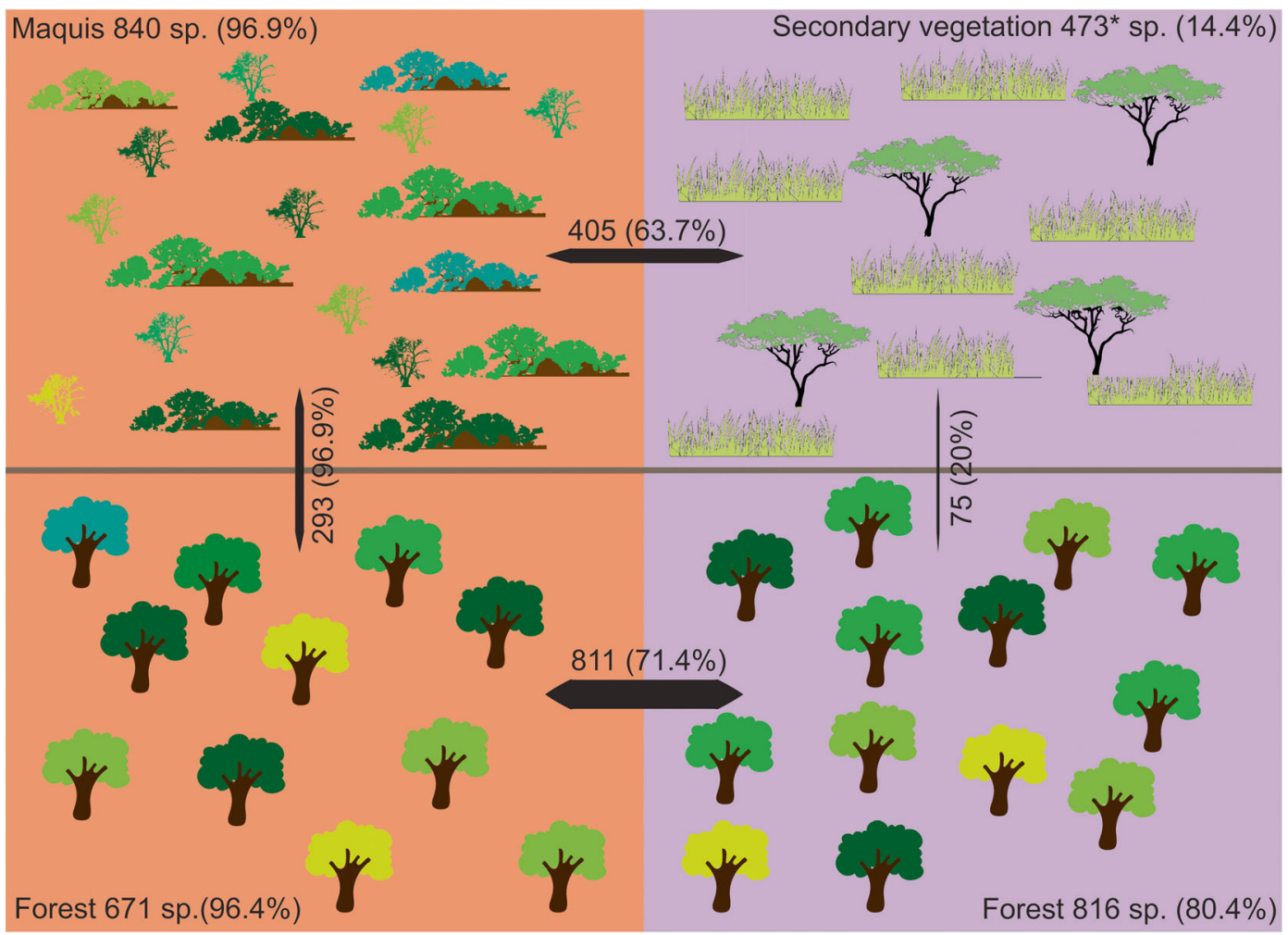

Fig. 4 Substrate-related flora in the different vegetation types: $[t o p]$ : non-forest vegetation; [bottom]: forest; [left]: ultramafic obligate flora; [right]: other-soil obligate flora. Number of species and endemism (in bracket). *the non-forest vegetation includes savannas, thickets on non-ultramafic or calcareous substrates,

vegetation on siliceous soils ("maquis on siliceous", Fig. 1b) whose floristic composition is close to the ultramafic maquis on degraded Ferralsols (Jaffré et al. 2012) (Fig. 4). This explains the relatively large number of species shared between maquis and other vegetation and attests to the selective effect of soil chemistry (i.e. acidity, low nutrient contents) in species sorting. The maquis encompass a wide spatial disparity in species richness from poor ( $\sim 14$ species) in the lignoherbaceous maquis on hydromorphic alluvium to rich ( $\sim 131$ species) of the shrubby maquis on Magnesic Cambisols (Jaffré 1980).

The high distinctiveness of the maquis versus other non-forest vegetation, contrasts with the forests that does not differ physiognomically from one edaphic condition to another. The structure of New Caledonian rainforest is characterized by a high density of small diameter stems regardless of the soil type (Ibanez et al. 2013). Secondary forest on Ferralsols is highly distinctive, often dominated by Nothofagus spp. maquis on siliceous substrates and acid soils in altitude, wetland, and halophile vegetation. Note that the non-ultramafic forest flora, as treated here, includes both rainforest and dry forest. Numbers above arrows indicate facultative species and endemism level

(Nothofagaceae) (Read et al. 2000), Arillastrum gummiferum (Myrtaceae) (Jaffré 1980), Gymnostoma spp. (Casuarinaceae) (Jaffré et al. 1994; McCoy et al. 1999) or Cerberiopsis candelabra (Apocynaceae) (Read et al. 2008). The flora is less rich in the ultramafic forest (Fig. 4) and roughly similar in plots of the southern massif on ultramafic soils (on Ferralsols) and on the whole main island on acid soils (i.e. non-ultramafic) (Ibanez et al. 2014; Jaffré and Veillon 1995). Thus, despite covering a smaller area (Table 5), ultramafic forests have slightly lower plant diversity than forests on non-ultramafic soils. Endemism is noticeably higher in ultramafic forest, reaching levels comparable to the maquis (Fig. 4). The relatively low level of endemism of the forest flora occurring exclusively on non-ultramafic soils can however be explained by the low level of endemism in dry forests (59.2\%, Morat et al. 2012) and rainforests on calcareous soil (52\%, Morat et al. 2001). Both forest types are strongly disturbed by repeated fire or invasive species. Rainforest on other soils 
contains a quite high number of endemics ( $83 \%$, Morat et al. 2012). Soils clearly constitute an ecological barrier, since $65 \%$ of forest species are confined to one type of substrate (Fig. 4). Forests nevertheless share a higher percentage of soil-facultative species than the total flora. This floristic affinity is possibly higher for large rainforest trees (DBH $\geq 10 \mathrm{~cm}$ ) (Birnbaum et al. 2015). Tree species have also been suggested to be less soilspecialized in Sabah (van der Ent et al. 2015b). The rainforests on both soil types are similar in their structure and diversity (Ibanez et al. 2014; Jaffré and Veillon 1995). The soil affinity is a reduced barrier in rainforest, allowing more species overlap. Rainforest conditions, i.e. canopy and litter make water and nutrient less limiting irrespective of the soil type or lithology (Table 2), reducing the soilrelated competitive exclusion. The largest areas of rainforest on ultramafic soils are located in the southern massif (Fig. 1), where rainfall is the highest even at low elevations. This geographical isolation and reduce water deficit could explain the high level of endemism found in ultramafic rainforest.

Several families under-represented on ultramafic soils mainly occurr in forests (e.g. Malvaceae, Moraceae). Few families are exclusively found in rainforest (e.g. Nothofagaceae, Paracryphiaceae, Phellinaceae) and have a strong affinity for ultramafic soils. Basal angiosperms, mainly occurring in rainforest (Pouteau et al. 2015) are equally represented on ultramafic and nonultramafic soils (Table 4). Niche modeling of 60 basal angiosperm species showed a higher species overlap on non-ultramafic soils and suggests that, rather than an affinity for a particular soil type, the distribution of basal angiosperms is mainly driven by a preference for rainforest habitats (Pouteau et al. 2015). Similar climate-driven distribution pattern was suggested for palms, the substrate being subordinate to climate (Pintaud et al. 2001).

Conversely, non-forest dominant families such as the Poaceae are predominantly restricted to non-ultramafic soils, and a very low proportion $(\sim 6 \%)$ is restricted to ultramafic soils. The vast majority of species in the Poaceae occur in contact zones at the base of ultramafic massifs and on serpentinite veins surrounded by savanna. The presence of ultramafic ecotypes, i.e. populations locally adapted to specific soils, as found in other areas worldwide (Burgess et al. 2015; Chathuranga et al. 2015; Kruckeberg 1984; O’Dell and Rajakaruna 2011) have not been investigated.
It seems obvious that the non-forest vegetation, which results mainly from repetitive fires on both ultramafic (Jaffré et al. 1998b; McCoy et al. 1999) and other soils (Ibanez et al. 2013), increases the differences between the ultramafic and the non- ultramafic floras. This was also suggested by Proctor (2003) for the vegetation on ultramafic soils in Malaysia and the Philippines.

\section{Plant adaptations to ultramafic soils}

Adaptation to ultramafic soils is widely proposed to be related with physiological prerequisites (Cecchi et al. 2011). The "serpentine syndrome" is related to adaptation to dry soil and nutrient limitation, which are major sources of stress in ultramafic environments (Kazakou et al. 2008). In New Caledonia, the disharmony of the flora, as commonly observed on islands, is mainly driven by pre-adaptation to ultramafic soils while dispersal limitation played a less important role (Pillon et al. 2010). Most of the over-represented lineages would have benefited from pre-adaptation to ultramafic soils that favored settlement and diversification (Jaffré et al. 1987; Pillon et al. 2010). This hypothesis is further supported by recent studies where ultramafic tolerance was reconstructed as plesiomorphic in some clades (Barrabé 2013; De Kok 2002; Pillon et al. 2009). The question, however, arises as to what traits facilitate colonization onto ultramafic soils, since plants found on ultramafic soils have to adapt to both drought and soil chemical stresses (Brady et al. 2005), but also bare soils (Cacho and Strauss 2014).

Tolerance to nutrient-poor and harsh environments

The ability of some lineages to grow on ultramafic soils is related to their tolerance for low nutrient conditions as shown by the low concentration of these elements in their leaves, especially the maquis species (Table 6). For example, P-concentrations are extremely low in all ultramafic soils (Table 1), and consequently at very low foliar concentrations $(90 \%$ have $<0.05 \% \mathrm{P})$ in the shrubby species of the maquis (Jaffré 1980). Conifers too have low foliar P and $\mathrm{K}$, as well as a low capacity to limit the uptake of Mn and Ni (Jaffré 1995). The dominance of conifers growing on ultramafic soils was also reported in California (Kruckeberg 2002) and Sabah (van der Ent 
Table 6 Foliar concentrations (dry mass basis) of major elements in three categories of maquis on ultramafic soils (Jaffré 1980)

\begin{tabular}{llllllll}
\hline & & $\mathrm{N}(\%)$ & $\mathrm{P}(\%)$ & $\mathrm{K}(\%)$ & $\mathrm{Ca}(\%)$ & $\mathrm{Mg}(\%)$ & $\mathrm{Mg} / \mathrm{Ca}$ \\
\hline Maquis on Magnesic Cambisols $(n=100)$ & Mean & 1.03 & 0.034 & 0.81 & 1.04 & 0.51 & 0.65 \\
& Range $(90 \%$ of sp.) & $0.55-1.39$ & $0.014-0.053$ & $0.26-1.54$ & $0.35-1.55$ & $0.14-0.84$ & $0.33-5.00$ \\
Maquis on eroded Ferralsols $(n=58)$ & Mean & 0.82 & 0.032 & 0.69 & 1.08 & 0.36 & 0.48 \\
& Range (90 \% of sp.) & $0.48-1.04$ & $0.011-0.044$ & $0.18-1.30$ & $0.35-1.85$ & $0.10-0.70$ & $0.29-1.67$ \\
Maquis on Plinthic Ferralsols $(n=100)$ & Mean & 0.91 & 0.032 & 0.59 & 1.10 & 0.24 & 0.27 \\
& Range (90 \% of sp.) & $0.48-1.39$ & $0.014-0.041$ & $0.15-1.10$ & $0.25-2.05$ & $0.06-0.60$ & $0.14-1.25$ \\
& & &
\end{tabular}

et al. 2014). Despite very high soil Mg concentrations in Magnesic Cambisols, $\mathrm{Mg}$ is often found at normal concentration in the leaves of shrubby species from the maquis, and an unbalanced $\mathrm{Mg} / \mathrm{Ca}$ has been little recorded in plants growing on these soils (Jaffré 1980).

Sclerophylly and microphylly

Low leaf nutrient concentration in plants from the maquis reflects a high degree of scleromorphic adaptations, with vegetation described as 'sclerophyll' (Jaffré 1980) or xerophyll (Virot 1956). There is, however, a longterm debate as to whether sclerophylly is an adaptation or a consequence of seasonal water deficit or to soil nutrient deficits (Kruckeberg 1954; Lamont et al. 2002). By comparing leaf mechanical properties, as a proxy for sclerophylly, in two contrasting environments (i) maquis on nutrient-deficient (Magnesic Cambisols) but moist conditions and (ii) dry forest in higher-nutrient soils but drier sites, Read et al. (2006b) found that maquis leaves were on average more "sclerophyllous" than those in dry forest. It was however noted that despite higher rainfall, maquis plants are facing water deficits in the dry season (Read et al. 2006b). Another study showed that leaf physical traits of maquis species in wet conditions in New Caledonia did not significantly differ from those of species in Mediterranean climate kwongan on low-nutrient soils in southwestern Australia (Read et al. 2007). This is suggestive of a stronger influence of soil-nutrient properties than rainfall on sclerophylly; nevertheless, these studies suggested that sclerophylly is a complex phenomenon where mechanical properties reflect both an adaptive response and a by-product of anatomical adaptation to a stressful environment. Sclerophylly is a syndrome resulting from adaptive responses to various stresses. For instance, leaf strength and toughness are also associated with herbivory stresses that increase in bare environments, as in some maquis. In New Caledonia, the shrubby to bushy maquis on deep Ferralsols in areas receiving high rainfall (2000-4000 mm) may be used to study the effect of water deficits on sclerophylly. Low concentrations of $\mathrm{N}$ and $\mathrm{P}$, in these deep Ferralsols, appear to be important together with the effects of intensive solar radiation (Jordan et al. 2005). Whatever the ecophysiological significance of sclerophylly, the strong floristic affinities of the New Caledonia maquis flora with that of Australian "heathlands" on poor soils, is suggestive of pre-adaptation of sclerophyllous species that colonized the maquis in New Caledonia (Morat et al. 1994, 1986). In California, drought-related leaf traits were present in the ancestors of chaparral lineages, before the advent of Mediterranean-type climate (Ackerly 2004).

Nutritional strategies in nutrient-deficient soils

Fewer studies have been conducted on nutrientacquisition strategies in New Caledonian plants, compared to other ultramafic regions (e.g. Europe, California, Australia), but a wide array are currently known. Ectomycorrhizal symbioses are found in Nothofagaceae and some Myrtaceae (Leptospermoïdeae) (Perrier et al. 2006), $\mathrm{N}_{2}$-fixing symbiosis occurs in the Casuarinaceae (Gauthier et al. 1999) and in the Fabaceae (Chaintreuil et al. 2007). Mycorrhizal symbioses are known to enhance Pacquisition from low-P soils by "scavenging strategies" (Lambers et al. 2008; Smith and Read 2008). For the vast majority of maquis species, the acquisition of $\mathrm{P}$ is favoured by symbiotic associations with arbuscular mycorrhizal fungi (AM) and with ectomycorrhizal fungi (ECM) for a smaller number of species (Amir et al. 2013). Leaf $\mathrm{N}$ concentrations of shrubby species in the 
maquis are low, less than $1 \%$ in $>60 \%$ of species (Jaffré 1980). Foliar N-concentrations $>2 \%$ are uncommon and mainly recorded in the Fabaceae (Acacia, Archidendropsis, Serianthes and Sophora, whose roots form nodules with symbiotic $\mathrm{N}$-fixing Rhizobium. Some non-mycorrhizal species display specialized rootadaptations such as cluster roots in the Proteaceae or dauciform roots (i.e. carrot-shaped) reported in some tribes of the Cyperaceae (Shane et al. 2006). These specialized roots are known to facilitate P-acquisition through the release of carboxylates (Lambers et al. 2014). Several species belonging to the genera Costularia and Schoenus (Cyperaceae) are pioneer species on mining substrates (Jaffré 1977a). These species have been recommended for restoration of mining sites (Wulff et al. 2010).

The vast majority of studies dealing with the role of nutrition-acquiring strategies in plant ecology in New Caledonia focus on mono-dominant and gregarious species. Mycorrhizal symbioses are known to confer a competitive advantage to such species by enhancing their growth rate and their ability to access soil nutrients, especially P. Acacia spirorbis (Mimosaceae) is known to exhibit a gregarious behaviour at low elevation on both ultramafic and non-ultramafic soils, and has ectomycorrhizal symbiosis (Jourand et al. 2014). The different species of Gymnostoma (Casuarinaceae) growing in mono-specific stands have a pioneer behaviour in the maquis (McCoy et al. 1999). The $\mathrm{N}_{2}$-fixing ability of root-bacteria (Frankia) in pioneer species of Gymnostoma enables faster growth to colonize bare or degraded soils (Reddell et al. 1986). While all Gymnostoma species in New Caledonia show a strong affinity for one soil type (Jaffré et al. 1994), no strict specific genotype of Frankia strain isolated from the root nodules of various species was associated with a specific host-plant (Navarro et al. 1999). Nevertheless several Frankia strains were exclusively associated with ultramafic soils (Navarro et al. 1999). The presence of ectomycorrhizal symbioses was also revealed in the genus Nothofagus, in several Tristaniopsis species (Perrier et al. 2006) and in Arillastrum gummiferum (Myrtaceae) (F. Carriconde, pers. comm.). The monodominance of Nothofagus in rainforest on ultramafic soils may result from a higher capacity to tolerate low nutrient conditions compared to co-occurring species (Read et al. 2002). The same hypothesis could apply for Tristaniopsis species that form monospecific stands in shrubby to bushy maquis and in margin forest vegetation, as for Arillastrum gummiferum which dominates the canopy of some rain forests on Ferritic Ferralsols.

\section{Hyperaccumulation of trace elements}

Plants with anomalous concentrations of particular trace elements (Ni or Mn) (e.g. $>1000 \mu \mathrm{g} \mathrm{g}^{-1} \mathrm{Ni}$ and 10 $000 \mu \mathrm{g} \mathrm{g}^{-1} \mathrm{Mn}$ ) are called "hyperaccumulators" (Jaffré et al. 1976; van der Ent et al. 2013). Concentration of these elements ( $\mathrm{Ni}$ and $\mathrm{Mn}$ ) in leaves of shrubby species growing on ultramafic soils is highly variable between species. On the 445 species tested in New Caledonia the mean foliar Mn concentration was $\leq 500 \mu \mathrm{g} \mathrm{g}^{-1}$ for 66.5 and $\sim 22 \%$ had 1000-10,000 $\mu^{g} \mathrm{~g} \mathrm{~g}^{-1}$ (Jaffré 1980). Foliar Mn concentrations $1.0-5.5 \%$ occur in 11 species (Losfeld et al. 2015). In contrast, of the about 500 plant species tested from New Caledonia, $67 \%$ had leaf Ni concentration $\leq 100 \mu \mathrm{g} \mathrm{g}^{-1}$ and $27 \%$ had 100-1000 $\mathrm{g} \mathrm{g} \mathrm{g}^{-1}$ (Jaffré 1980). Manganese hyperaccumulation occurs in various families and genera (e.g. Alyxia (Apocynaceae), Denhamia (Celastraceae), Garcinia (Clusiaceae), Gossia (Myrtaceae) and Polyscias (Araliaceae)) (Losfeld et al. 2015), with, a high proportion of Mn accumulating species in the Proteaceae (Jaffré 1979), clearly succeeding on ultramafic soils as shown by their over-representation of ultramafic obligate species. Manganese accumulation by some species growing on Magnesic Cambisols, with a basic $\mathrm{pH}$ constraining $\mathrm{Mn}$ uptake, is remarkable (Jaffré 1977b). In contrast, an acidic soil $\mathrm{pH}$ facilitates $\mathrm{Mn}$ acquisition (Fernando et al. 2008), and specialized root adaptations found in Proteaceae, which facilitate P-acquisition through the release of carboxylates, might also mobilize $\mathrm{Mn}$ (Lambers et al. 2015).

Strong variations in floristic richness in response to ultramafic-derived soil chemistry has been reported for New Caledonian rainforest (Jaffré and Veillon 1991). The depletion of species richness on alluvial Ferralsols, associated with modification of floristic composition, has been attributed to the high concentration of available $\mathrm{Ni}$ in the soil (Jaffré and Veillon 1991). Similar trends were observed for the ultramafic flora in Queensland where species richness was negatively correlated and endemism positively correlated with the available $\mathrm{Ni}$ concentrations in the soil (Batianoff and Singh 2001). Low species richness on sites with high Ni concentration might also be accentuated by allelopathy occurring under the canopy of $\mathrm{Ni}$ hyperaccumulator trees or 
shrubs. Nickel concentrations in both litter and topsoil can affect both germination and development of some seedlings providing a competitive advantage to $\mathrm{Ni}$ hyperaccumulator plants (Boyd and Jaffré 2001). Most of the research on the phenomenon of hyperaccumulation has focussed on Ni (Proctor 2003). In New Caledonia a total of 65 Ni-hyperaccumulators (foliar Ni concentrations $>1000 \mu \mathrm{g} \mathrm{g}^{-1}$ ) have been reported to date (Jaffré et al. 2013). Fifteen of these species have Ni concentrations $\geq 10,000 \mu \mathrm{g} \mathrm{g}^{-1}$ and may be called hypernickelophores (Boyd and Jaffré 2009; Jaffré and Schmid 1974).

Together with Cuba, with a reported $\sim 140$ hyperaccumulator species (Reeves et al. 1996; 1999), New Caledonia is a global hotspot of $\mathrm{Ni}$ hyperaccumulator plants with. 65 species belonging to 12 families and 20 genera (Jaffré et al. 2013). Most of the Ni-hyperaccumulator plants are ultramafic-obligates and occur in rainforest. The main families in which $\mathrm{Ni}$ hyperaccumulator plants occur in New Caledonia belong to the Order Malpighiales (Jaffré et al. 2013; van der Ent et al. 2015a). The large Cunoniaceae family (Oxalidales) has numerous Ni hyperaccumulator species in three genera. The Malpighiales and Oxalidales contain 54 hyperaccumulator species in New Caledonia, with the remaining 11 species spread over 10 genera, 7 families and 7 Orders (Jaffré et al. 2013). Even though the hyperaccumulator species of New Caledonia are taxonomically diverse, they cluster phylogenetically (Jaffré et al. 2013; Pillon et al. 2010). The reasons for the observed phylogenetic clustering remains unknown, but the time of exposure is probably important for the evolution of ultramafic endemics and hyperaccumulators. This can be illustrated by Cuba where the majority of hyperaccumulators are endemic to the oldest serpentine soils (Reeves et al. 1996, 1999). The fact that numerous hyperaccumulator species are found in ultramafic obligate-rich lineages could simply result from the greater chance for species to evolve hyperaccumulation. Examples include the genera Codia, Pancheria and Geissois (Cunoniaceae), the genus Pycnandra (Sapotaceae), the genus Phyllanthus (Phyllanthaceae), and the genera Xylosma and Homalium (Salicaceae).

High soil Ni concentration correlate with the occurrence of hyperaccumulator plants in Sabah, Malaysia (Van der Ent et al. 2016). In New Caledonian, hyperaccumulator plants in "Parc de la Rivière Bleue" occur on alluvial Ferralsols with high Ni concentrations
(Jaffré and Veillon 1991). Nickel accumulation was shown to be negatively correlated with habitatspecialization in Cuba (Borhidi 2001), which could help explain the lack of hyperaccumulator plants in the maquis of New Caledonia. A number of families overrepresented on ultramafic soils that are mostly ultramaficobligate (which occur on maquis) do not have any $\mathrm{Ni}$ hyperaccumulator species, for example the Ericaceae and Dilleniaceae.

New Caledonia phylogenetically diverse set of $\mathrm{Ni}$ hyperaccumulator plants offers opportunities to advance the knowledge of the molecular mechanisms involved with Ni hyperaccumulation (Callahan et al. 2012; Perrier et al. 2004). The identification of genes involved in Ni accumulation (Merlot et al. 2014) will be especially critical for identifying mechanisms involved in $\mathrm{Ni}$ hyperaccumulation and adaptations to ultramafic soils. Nickel absorption is affected by rhizosphere processes such as root physical characteristics, rhizosphere chemistry, and rhizosphere microorganisms (reviewed by Alford et al. 2010). Several studies conducted in New Caledonia have shown that bacteria were abundant and diverse, with some strains exhibiting high levels of Nitolerance (Gonin et al. 2013; Guentas et al. 2016; Hery et al. 2003). Similarly, mycorrhizas forming symbiotic associations with some species were found to have a high Ni-tolerance (Amir et al. 2013; Amir et al. 2007; Jourand et al. 2010).

\section{Occupation of bare habitats}

The bareness associated with some ultramafic sites in New Caledonia may represent a selective force for some habitat specialist plants. In California, adaption to microhabitat bareness was more conserved across clades than soil properties $(\mathrm{Mg}, \mathrm{Ni}, \mathrm{Ca} / \mathrm{Mg}$ ratio), and taxa from bare environments were also less competitive in greenhouse experiments (Cacho and Strauss 2014). Such a phylogenetic signal suggests that the ability to occupy bare environments might precede immigration onto ultramafic soils.

\section{Competitive exclusion}

The low number of species shared between maquis and other non-forest vegetation (savanna and secondary thickets) that together cover $>95 \%$ of the non-forest vegetation of New Caledonia, results from the strong selective pressures imposed by ultramafic soils. Slow- 
growing stress-tolerant species are less competitive and the edaphic barrier is well illustrated by changes in the flora at the base of ultramafic massifs on the west coast of Grande Terre (Jaffré and L'Huillier 2010). Similar distribution patterns have also been reported elsewhere on ultramafic-non-ultramafic geological boundaries (Brooks 1987; Kruckeberg 2002). In New Caledonia, many maquis species have been shown to grow in autoecological condition on other soils (Jaffré 1980), but they are likely excluded from these sites by interspecific competition. Competitive exclusion is widely known to limit ultramafic-tolerant species to ultramafic soils because of their slow growth rate and their inability to compete in less stressful environments (Anacker et al. 2011; Brady et al. 2005; Kruckeberg 1954). This exclusion then leads to species becoming restricted (endemic) to ultramafic sites.

In virtue of their high richness and local abundance in some forests and maquis on ultramafic soils, conifers are emblematic of this substrate in New Caledonia. New Caledonia hosts $7 \%$ (45 species) of the worldwide conifer flora, and conifers are known to be highly efficient at outcompeting angiosperms in unproductive sites where water and/or nutrients are limiting (Brodribb and Hill 1998; Brodribb et al. 2012; Enright and Hill 1995). With the exception of a few shade-tolerant Podocarp species, most of the species belonging to Araucaria, Podocarpus, Dacrydium and Callitris genera are lightdemanding, often growing on steep slopes of the ultramafic massifs (Jaffré 1995). Under these ecological conditions, conifers are able to overtop forest/maquis canopy and resist high wind exposure during the cyclone season. Studies on the ecology and population dynamics of Araucaria (Enright et al. 2014, 2001; Rigg et al. 2010) and Agathis (Enright et al. 2003) have shown their ability to grow in harsh environments on Ferralsols. The most extreme case of tolerance is Araucaria muelleri growing on Ferralsols. This species has a slow stand-dynamics, characterized by low recruitment and one of the lowest growth rates ever reported for any tree species worldwide (e.g. average stem diameter increase ranging from 0.1 to $0.3 \mathrm{~mm}$ per year) (Enright et al. 2014).

The ecological barrier imposed by ultramafic soil is also highlighted by the scarcity of introduced species. Approximately 500-600 naturalized species are found on non-ultramafic soils in New Caledonia (Hequet and Le Corre 2010; Meyer et al. 2006) while only about 10 species occur on ultramafic soils. These species persist (with a few exceptions such as Pinus caribaea) only in mixed zones or on sites strongly affected by human activities. The initial flora on non-ultramafic soils (metamorphic, volcano-sedimentary and calcareous) has been largely replaced by common and widespread species with pan-tropical or pan-pacific distribution, after clearings and repetitive fires.

\section{Factors influencing species richness and endemism on ultramafic soils}

Extend and age of ultramafic crops

The number of ultramafic endemics in the regional flora appears to be related to the percentage of the land area made up of ultramafic soils, simply because a large area provides more chances for species to adapt and become restricted (Anacker 2011). Among the other endemism hotspots, Cuba and California with respectively $27 \%$ (Anacker 2011) and 12.5\% (Safford et al. 2005) of their species endemic to ultramafic soils, New Caledonia has a substantially higher proportion of endemic species $(47.3 \%)$, while the areal extended is smaller (compare to Cuba with $7500 \mathrm{~km}^{2}$ of ultramafic soils). This may be explained by other factors that contribute to the very high level of ultramafic endemism in New Caledonia, including the age of ultramafic exposure and fragmentation of the peridotite mantle in isolated massifs across the Island. Age of ultramafic exposure is a predominant factor of soil-endemism and diversity in Cuba (Reeves et al. 1996, 1999).

Patchiness and environmental gradients

The range of soil types on ultramafic lithologies (Tables 1 and 5), some of the most varied globally, has been particularly important in the maquis, considering the high diversity of soil chemistry and physics (structure and depth) and isolation of ultramafic patches. As a consequence of the fragmented distribution, ultramafic outcrops are isolated 'edaphic islands' across the New Caledonian landscape. For example, "serpentine veins" typically form small isolated patches in non-ultramafic environments. This type of "patchiness" causes two ecologically important factors: environmental gradients and habitat discontinuity. When de-coupled from environmental gradients, patchiness affects floristic dissimilarity with extinction and colonization acting 
differentially among sites (Harrison 1997). In California patchiness strongly affects regional diversity through edge-effects (Harrison 1997). Whittaker (1954) reported greater changes in community composition along an elevation gradient for an ultramafic flora compared to a non-ultramafic flora. This may be explained by a stronger response of ultramafic endemic species to climatic conditions (precipitation) compared with nonendemic species (Harrison and Inouye 2002). The complex topography and climatic gradients in New Caledonia cause a wide diversity of habitats is an important driver for plant speciation, especially in the maquis. The maquis of New Caledonia range from low elevation $(<10 \mathrm{~m})$ to the summit of Mont Humboldt $(1816 \mathrm{~m})$ and is coupled with a edaphic heterogeneity (Table 5) enhancing patchiness and between-site diversity.

\section{Vegetation}

Although the forest flora on ultramafic soils has a greater total number of species compared to the maquis, the maquis harbors more habitat-specialised species. The maquis develops from forest impacted by fire and presents a harsh environment for species to persist. Though, maquis on poor soils are species poor but harbor a distinctive and endemic-rich flora. Tree cover has a significant impact on species composition through improvement of soil fertility, leading to a reduction of endemic species by the spread of competitive species (Chiarucci et al. 2001). In New Caledonia, the overrepresentation of some floristic groups is frequently related with occurrence in maquis. Lineages currently associated with maquis may have spread during the Pleistocene rainforest regression, and may have coincided with Pleistocene aridification, which has stimulated diversification in the (non-ultramafic) South African Cape flora (Richardson et al. 2001). As such, a drier climate may have opened ecological niches favorable to the extension of species adapted to dry forest (on nonultramafic soils) and maquis (on ultramafic soils). Diversification rates in New Caledonia have been the fastest in the youngest clades of the genus Dracophyllum (Ericaceae) which is restricted to maquis (Pillon 2012). This study however includes a single maquis-restricted lineage (Dracophyllum). More research is needed to highlight the role of in situ diversification (neo-endemism) on maquis endemism.
The distribution of rainforest lineages appears less influenced by soil types, as gauged by the even distribution of forest-affiliated groups in both edaphic compartments (e.g. basal angiosperms, palms, etc.). The current over-representation of basal angiosperms arose from the persistence of rainforest on the main island despite global Quaternary fluctuations that have affected regional floras (Pouteau et al. 2015). As such, rainforest species may have persisted in refugia, thus explaining the current disjointed distribution of some taxonomic groups. The disjointed distribution of many closelyrelated rainforest species is suggestive of fragmentation of a once continuous lowland rainforest that is likely to have persisted only in the northeast and south of Grande Terre during glacial maxima (Pintaud et al. 2001; Pouteau et al. 2015). The relatively large fraction of ultramafic-obligate species (293 spp.) shared between forest on ultramafic substrate and maquis could result from maquis species persisting in closed forest and forest species persisting after fire on bare ultramafic soils.

\section{Diversification and endemism through the prism of ultramafic soils}

\section{Lack of large radiation}

In New Caledonia, adaptions to ultramafic soils have evolved independently in a wide range of different plant groups. The evolutionary origin is highly labile, as has been shown by mapping tolerance over phylogenies in California (Anacker 2011), and as was shown for Palms (Pintaud and Jaffré 2001), for the genus Psychotria (Rubiaceae) (Barrabe et al. 2014) and Polyscias (Araliaceae) (Eibl et al. 2011). Widespread adaptive radiation in the New Caledonian flora appears rare, however (Pillon 2012) and have been little studied within ultramafic clades. The largest known radiation in the New Caledonian flora, which has occurred in the clade NC2 of the genus Psychotria (Rubiaceae), is not strictly associated with habitat specialization on ultramafic soils but has diversified on various types of soils (Barrabé 2013). More than $30 \%$ of Psychotria species are ultramafic endemics but no phylogenetic signal could be detected for ultramafic tolerance (Barrabé 2013). In the genus Pycnandra (Sapotaceae), the largest endemic plant genus of New Caledonia (Morat et al. 2012), $60 \%$ of the 66 species are ultramafic obligates and 
adaptive radiation on ultramafic soils does not appear to have occurred (Swenson et al. 2008). In the genus Geissois (Cunoniaceae) the radiation of 13 species from a single colonist results from rapid diversification on contrasting soil substrates (Pillon et al. 2014). Concluding, the current phylogenetic pattern in the largest genera of the New Caledonian flora favor polyphyletic origins of ultramafic tolerance which suggest that ultramafic tolerance is evolutionary labile. This pattern is also congruent with the idea that shifts in soil preference, rather than radiation on a single soil type, is a main driver for diversification. This is confirmed by high endemicity, but low diversity, of soil-obligate genera, while species-rich genera are soil-facultative in New Caledonia. Elsewhere, despite the strong selective pressure on ultramafic soils which promotes adaptations, soil endemism is also not associated with adaptive radiation in California (Anacker 2011, 2014; Anacker et al. 2011; Schnitzler et al. 2011).

New Caledonian old communities and recent colonization events

The New Caledonian flora is distinct from other superspecies rich floras associated with edaphic conditions, such as the South African Cape fynbos and the kwongan of Southwestern Australia, neither of which are ultramafic, where large (explosive) radiations represent a large proportion of the flora (Hopper and Gioia 2004; Richardson et al. 2001). The old age of New Caledonian flora may explain the low rates of diversification found in several New Caledonian lineages (Pillon 2012). Extinction events over the Island's geological history could further increase its phylogenetic isolation of numerous taxa (Pillon 2012). This appears to hold for habitat specialist endemic species with low infrageneric and infra-family diversity. Most of the Uo genera number $<5$ species and 20 of these genera are monospecific. There are eight Uo families that are monogeneric and contain less than five species each. The low diversity of ultramafic obligate genera or families may also be explained from extinction events inside formerly diverse clades. This relictual diversity is illustrated by several putative paleo-endemic lineages, such as the mono-generic Strasburgeria which is thought to have been widely distributed in Antarctic region in the early Eocene (Contreras et al. 2013). Other putative paleo-endemic lineages include the endemic monospecific genera Paracryphia (Paracryphiaceae) and
Nemuaron (Atherospermataceae), and the endemic family Phellinaceae that dates back to mid to late Cretaceous (Bremer et al. 2004). There are currently no known examples of old diversification in New Caledonia, instead groups such as Araucaria or Nothofagus are of recent origin (Grandcolas et al. 2008). Furthermore, multiple dispersal events have occurred in numerous groups (Barrabe et al. 2014; Bartish et al. 2005). New immigrants that colonized the Island had to compete with older lineages, potentially preventing widespread radiation to occur. For more recently diversified lineages, low species richness could reflect lower diversification of habitat specialist lineages compared to generalist lineages, as in the Californian flora (Anacker et al. 2011). As such, both extinction and competition might explain why adaptive radiation is not observed today (Pillon 2012). More studies are needed to elucidate the diversification age and rates of the New Caledonian relictual lineages.

Edaphic islands

Few studies have focused on the role of ultramafic soils in promoting the levels of endemism in New Caledonia. In contrast, in California, the pivotal role of edaphic factors and habitat patchiness in promoting plant speciation and endemism have been well-studied (Kay et al. 2011; O’Dell and Rajakaruna 2011; Rajakaruna 2004; Rajakaruna and Baker 2004). In other regions, such as Southeast Asia (Chathuranga et al. 2015; Rajakaruna and Baker 2004; van der Ent et al. 2015b), in Europe (Cecchi et al. 2011; Cecchi et al. 2010; Mengoni et al. 2003; Stevanović et al. 2003) and in South Africa (Schnitzler et al. 2011) similar studies have already been undertaken. These studies stress that patchiness of soils is likely to contribute to the geographic isolation of populations, through so called "edaphic islands" (Kruckeberg 1991; Rajakaruma and Boyd 2008; Rajakaruna 2004). In New Caledonia, ultramaficendemic genera and families combine both edaphic and geographic isolation in the mountainous cordillera of Grande Terre and wetlands of the "Plaine des Lacs". The distribution of several hyper-endemic plant species on isolated massifs supports allopatric speciation as a most common mode for speciation in New Caledonia (Mouly and Jeanson 2015). In the genus Geissois, species growing on ultramafic soils are weakly ecologically differentiated (concentration of elements: $\mathrm{Al}, \mathrm{Ca}, \mathrm{Cr}, \mathrm{Fe}$, $\mathrm{Mg}, \mathrm{Ni}, \mathrm{P}$ ) and are thought to have radiated through 
allopatric speciation (Pillon et al. 2014). Similarly, an allopatric model of speciation was proposed for some species of Polyscias (Araliaceae) occurring on ultramafic soils (Eibl et al. 2011). Further evidence for allopatric speciation on isolated massifs is provided in Wulff et al. (2013).

The few zones where different edaphic conditions are in close proximity might also have been important in providing evolutionary opportunities for adjacent populations. For instance, the parapatric distribution of several species belonging to Burretiokentia (Arecaceae), in the narrow contact zone, suggests a potential case of parapatric speciation. Burretiokentia vieillardii has a wide geographic distribution and occurs on both metamorphic rocks and Ferralsols, while its two sister species, B. dumasii and B. koghiensis, are found on two isolated ultramafic massifs (Me Maoya and Mont Koghis) of which only on Magnesic Cambisols (Pintaud and Jaffré 2001). These two species that are adapted to the distinctive Magnesic Cambisols represent possible cases of adaptive radiation (Pintaud and Jaffré 2001) and may have descended from the more widespread species $B$. vieillardii. On Mont Koghis, which consists of a complex matrix of different soils (Ferralsols, Magnesic Cambisols and sedimentary soils), mixes species that elsewhere do not co-occur. This site may have permitted hybridization for at least one endemic Cunoniaceae (Cunonia koghicola) (Pillon et al. 2008).

\section{Conclusions}

The flora of New Caledonia is typified by the occurrence of ultramafic outcrops that disproportionally contributes to the high levels of plant diversity and endemism on the Island. The so-called maquis vegetation, which has evolved relatively recently, as a result of repetitive fires and climatic fluctuations, is the main contributor to the distinctiveness of the ultramafic flora. Rainforest on ultramafic soils, though less exposed to harsh environments, also harbors an original and rich flora that is currently threatened by anthropogenic activities causing rainforest regression that will lead to the loss of many soil-endemic species. The edaphic heterogeneity of ultramafic soils is combined with a complex topography and severe isolation of ultramafic patches constituting edaphic islands known as drivers of plant speciation and endemism. The ultramafic flora exhibits a range of nutrient-acquisition strategies and other adaptive traits (trace element hyperaccumulation, sclerophylly). Ultramafic soils are arguably an efficient ecological barrier against plant colonist and might thus have efficiently protected New Caledonia flora against exotic plant species. Attributes of invasive exotic plants strongly differ from attributes required to grow in harsh environment. The richness of the ultramafic flora diversity is likely to have resulted from repeated independent dispersal events of pre-adapted species, rather than in situ radiation on this substrate. Paleo-endemic lineages, illustrating the relatively old age of New Caledonian flora and regional climatic events that occurred during Pleistocene, further add to phylogenetic distinctness and endemism. These factors may explain the low number of genera and families observed in many ultramafic obligate lineages and the disjoint distribution of many closely-related species. This hypothesis however, remains to be tested and involves detailed phylogenetic studies especially on maquis species. In the future, we plan to perform meta-analyses on our extensive dataset to unravel the relationships between geographical and soil factors and possible the correlations to patterns of endemism and species richness.

The extended of forest has been greatly reduced due to repeated fires since human settlement $\sim 3300$ years ago (Ibanez et al. 2013; Perry and Enright 2002). More recently, the vegetation on ultramafic soils is under acute threat by nickel mining activities (Jaffré et al. 1998a; L'Huillier et al. 2010; Wulff et al. 2013). Today, forests are restricted to mountainous locations (mainly on Ferralsols above $850-1000 \mathrm{~m}$ asl), on alluvial soils along rivers, in thalwegs on rock slides, and in valleys as scattered relicts protected from fire and mining activities (Jaffré et al. 2010). Only a few relict patches of forest (each $<1$ ha) remain on Magnesic Cambisols at the base of massifs in the more arid zone. The vulnerability of the ultramafic flora is illustrated by the conifers, of which 23 species of 41 occurring on ultramafic soils are now threatened (5CR, $12 \mathrm{EN}, 6 \mathrm{VU})$ (Jaffré et al. 2010). Of 95 hyper-endemic species occurring on mining sites, 80 have been evaluated as threatened (18CR, $41 \mathrm{EN}, 21 \mathrm{VU}$ ) by the local Read List Authority (RLANC). This assessment is in progress and does not include all hyper-endemic species affected by mining activities. Habitat fragmentation exacerbates further biodiversity loss due to the low genetic diversity of small-sized populations of many endemic plant species (Honnay and Jacquemyn 2006; Kettle et al. 2007). The integral 
protection of all remaining forest on ultramafic soils, and that of some maquis on Magnesic Cambisols, should be a priority. The ultimate effects of climate change are currently unknown, but expected to pose a threat to many habitat specialist plant species in New Caledonia. Specific vulnerability also comes from low dispersal ability, the restricted area for migration, the small population size and the high proportion of habitat specialists (Harter et al. 2015; Taylor and Kumar 2016). The dual insularity syndrome of the New Caledonian ultramafic flora involved further vulnerability to climate changes.

Acknowledgments We thank the Herbarium of IRD in Noumea (NOU), the National Museum of Natural History in Paris (P), and the Missouri Botanical Gardens in St. Louis (MO) whose collections have served as sources of information. Our thanks also go to botanists undertaking taxonomic revisions of the families of the New Caledonian flora, who provided information on the studied species: J.W. Dawson, the late Lyn A. Craven, N. Snow for Myrtaceae, M. Callmander for Pandanaceae, H. Hopskin and Y. Pillon for Cunoniaceae, P.P. Lowry and F. Tronchet for Araliaceae, J. Munzinger \& U. Swenson for Sapotaceae, M. Schmid for Primulaceae, P. Morat for Malvaceae, F. Achille, L. Barrabé and A. Mouly for Rubiaceae. We also thank Robin Pouteau (IAC) and anonymous reviewers for their valuable comments on the manuscript. We thank Hans Lambert and Antony Van der Ent for their invitation to submit this paper and their input to increase the clarity of this manuscript.

\section{References}

Ackerly D (2004) Adaptation, niche conservatism, and convergence: comparative studies of leaf evolution in the California chaparral. Am Nat 163:654-671. doi:10.1086/383062

Alford ER, Pilon-Smiths EAH, Paschke MW (2010) Metallophytes - a view from the rhizosphere. Plant Soil 337:33-50

Amir H, Perrier N, Rigault F, Jaffré T (2007) Relationships between Ni hyperaccumulation and mycorrhizal status of different endemic plant species from New Caledonian ultramafic sols. Plant Soil 293:23-35

Amir H, Jourand P, Cavaloc Y, Ducousso M (2013) Role of mycorrhizal fungi on the alleviation of heavy metal toxicity on plant. In: Solaiman Z, Abbott L, Varma A (eds) Mycorrhizal fungi: use in sustainable agriculture and forestry. Springer, Heidelberg

Anacker BL (2011) Phylogenetic patterns of endemism and diversity. In: Harrison SP, Rajakaruma N (eds) Serpentine: the evolution and ecology of a model system. University of California Press, Los Angeles

Anacker BL (2014) The nature of serpentine endemism. Am J Bot 101:219-224. doi:10.3732/ajb.1300349
Anacker BL, Whittall JB, Goldberg EE, Harrison SP (2011) Origins and consequences of serpentine endemism in the California flora. Evolution 65:365-376

Aubréville A, Leroy J-F, MacKee HS, Morat P (eds) (1967-) Flore de la Nouvelle-Calédonie et Dépendances. Muséum National d'Histoire Naturelle, Paris

Bani A, Echevarria G, Montargès-Pelletier E, Gjoka F, Sulçe S, Morel JL (2014) Pedogenesis and nickel biogeochemistry in a typical Albanian ultramafic toposequence. Environ Monit Assess 186:4431-4442. doi:10.1007/s10661-014-3709-6

Barrabé L (2013) Systématique et Evolution du genre Psychotria (Rubiaceae) en Nouvelle-Calédonie. Université de la Nouvelle-Calédonie

Barrabe L, Maggia L, Pillon Y, Rigault F, Mouly A, Davis AP, Buerki S (2014) New Caledonian lineages of Psychotria (Rubiaceae) reveal different evolutionary histories and the largest documented plant radiation for the archipelago. Mol Phylogenet Evol 71:15-35. doi:10.1016/j.ympev. 2013.10.020

Bartish IV, Swenson U, Munzinger J, Anderberg AA (2005) Phylogenetic relationships among New Caledonian Sapotaceae (Ericales): molecular evidence for generic polyphyly and repeated dispersal. Am J Bot 92:667-673

Batianoff GN, Singh S (2001) Central Queensland serpentine landforms, plant ecology and endemism. S Afr J Sci 97: 495-500

Becquer T, Bourdon E, Petard J (1995) Disponibilité du nickel le long d'une toposéquence de sols développés sur roches ultramafiques de Nouvelle-Calédonie. C R Acad Sci II A 321:585-592

Becquer T, Rigault F, Jaffré T (2002) Nickel bioavailability assessed by ion exchange resin in the field. Commun Soil Sci Plant Anal 33:439-450

Birnbaum P, Ibanez T, Pouteau R, Vandrot H, Hequet V, Blanchard E, Jaffré T (2015) Environmental correlates for tree occurrences, species distribution and richness on a high-elevation tropical island. AoB Plants. doi:10.1093/aobpla/plv075

Borhidi A (1991) Phytogeography and vegetation ecology of Cuba. Akademiai Kiado, Budapest

Borhidi A (2001) Phylogenetic trends in Ni-accumulating plants. S Afr J Sci 97:544-547

Boyd RS, Jaffré T (2001) Phytoenrichment of soil content by Sebertia acuminata in New Caledonia and concept of elemental allelopathy. S Afr J Sci 97:535-538

Boyd RS, Jaffré T (2009) Elemental concentration of eleven New Caledonian plant species from serpentine soils: elemental correlations and leaf age effects. Northeast Nat 16:93-110

Brady KU, Kruckeberg AR, Bradshaw HD Jr (2005) Evolutionary ecology of plant adaptation to serpentine soils. Annu Rev Ecol Evol Syst 36:243-266. doi:10.1146/annurev.ecolsys.35. 021103.105730

Bremer K, Friis EM, Bremer B (2004) Molecular phylogenetic dating of asterid flowering plants shows early cretaceous diversification. Syst Biol 53:496-505

Brodribb TJ, Hill RS (1998) The photosynthetic drought physiology of a diverse group of Southern Hemisphere conifer species is correlated with minimum seasonal rainfall. Funct Ecol 12:465-471

Brodribb TJ, Pittermann J, Coomes DA (2012) Elegance versus Speed: examining the Competition between Conifer and Angiosperm Trees. Int J Plant Sci 173:673-694 
Brooks RR (1987) Serpentine and its vegetation: a multidisciplinary approach viii. Geological Magazine 123. Croom Helm, Dioscorides Press, Kent. 454 pp

Burgess J, Szlavecz K, Rajakaruna N, Swan C (2015) Ecotypic differentiation of mid-Atlantic Quercus species in response to ultramafic soils. Aust J Bot 63:308-323

Cacho NI, Strauss SY (2014) Occupation of bare habitats, an evolutionary precursor to soil specialization in plants. Proc Natl Acad Sci U S A 111:15132-15137

Callahan DL, Roessner U, Dumontet V, De Livera AM, Doronila A, Baker AJM, Kolev SD (2012) Elemental and metabolite profiling of nickel hyperaccumulators from New Caledonia. Phytochemistry 81:80-89

Cecchi L, Gabbrielli R, Arnetoli M, Gonnelli C, Hasko A, Selvi F (2010) Evolutionary lineages of Ni-hyperaccumulation and systematics in European Alysseae (Brassicaceae): evidence from nrDNA sequence data. Ann Bot 106:751-767

Cecchi L, Coppi F, Selvi F (2011) Evolutionary dynamics of serpentine adaptation in Onosma (Boraginaceae) as revealed by ITS sequence data. Plant Syst Evol 297:185-199

Chaintreuil C, Rigault F, Moulin L, Jaffré T, Fardoux J, Guiraud E, Dreyfus B, Bailly X (2007) Nickel resistance determinants in Bradyrhizobium strains from nodules of the endemic New Caledonian legume Serianthes calycina. Appl Environ Microbiol 73:8018-8022

Chathuranga PKD, Dharmasena SKAT, Rajakaruna N, Iqbal MCM (2015) Growth and nickel uptake by serpentine and non-serpentine populations of Fimbristylis ovata (Cyperaceae) from Sri Lanka. Aust J Bot 63:128-133. doi: 10.1071/BT14232

Cheng C-H, Jien S-H, Iizuka Y, Tsai H, Chang Y-H, Hseu Z-Y (2011) Pedogenic chromium and nickel partitioning in serpentine soils along a toposequence. Soil Sci Soc Am J 75: 659. doi:10.2136/sssaj2010.0007

Chevillotte V, Chardon G, Beauvais A, Maurizot P, Colin F (2006) Long-term tropical morphogenesis of New Caledonia (Southwest Pacific): importance of positive epeirogeny and climate change. Geomorphology 81:361-375

Chiarucci A, Rocchini D, Leonzio C, De Dominicis V (2001) A test of vegetation-environment relationship in serpentine soils of Tuscany, Italy. Ecol Res 16:627-639. doi:10.1046/j. 1440-1703.2001.00437.x

Contreras L, Pross J, Bijl PK, Koutsodendris A, Raine JI, van de Schootbrugge B, Brinkhuis H (2013) Early to Middle Eocene vegetation dynamics at the Wilkes Land Margin (Antarctica). Rev Palaeobot Palynol 197:119-142. doi:10.1016/j. revpalbo.2013.05.009

Cowling RM, Holmes PM (1992) Flora and vegetation. In: RM Cowling (ed) The ecology of fynbos: nutrients, fire and diversity. Oxford University Press

Cowling RM, Lombard AT (2002) Heterogeneity, speciation/ extinction history and climate: explaining regional plant diversity patterns in the Cape Floristic Region. Divers Distrib 8:163-179

De Kok R (2002) Are plant adaptations to growing on serpentine soil rare or common? A few case studies from New Caledonia. Adansonia 24:229-238

Eibl JM, Plunkett GM, Lowry PP II (2011) Evolution of Polyscias sect. Tieghemopanax (Araliaceae) based on nuclear and chloroplast DNA sequence data. Adansonia 23:23-48
Enright NJ, Hill RS (1995) Ecology of the southern conifers. Melbourne University Press, Carlton, Australia

Enright NJ, Rigg L, Jaffré T (2001) Environmental controls on species composition along a (maquis) shrubland to forest gradient on ultramafics at Mt Do, New Caledonia. S Afr J Sci 97:573-580

Enright NJ, Miller BP, Perry GLW (2003) Demography of the long-lived conifer Agathis ovata in maquis and rainforest, New Caledonia. J Veg Sci 14:625-636

Enright NJ, Miller BP, Perry GLW, Goldblum D, Jaffré T (2014) Stress-tolerator leaf traits determine population dynamics in the endangered New Caledonian conifer Araucaria muelleri. Austral Ecol 39:60-71

Fernando DR, Woodrow E, Jaffré T, Dumontet V, Marshall AT, Baker AJM (2008) Foliar manganese accumulation by Maytenus fournieri (Celastraceae) in its native New Caledonia habitats: populational variations and localisation by x ray microanalysis. New Phytol 177:178-185

Fritsch E (2012) Les sols. In: Bonvallot J, Gay J-C, Habert E (eds) Atlas de la Nouvelle-Calédonie. IRD \& Congrès de la Nouvelle-Calédonie, Marseille

Garnier J, Quantin C, Guimarães E, Garg VK, Martins ES, Becquer T (2009) Understanding the genesis of ultramafic soils and catena dynamics in Niquelândia, Brazil. Geoderma 151:204-214. doi:10.1016/j.geoderma.2009.04.020

Gauthier D, Navarro I, Rinaudo G, Jourand P, Jaffré T, Prin Y (1999) Isolation, characterisation (PCR-RFLP) and specificity of Frankia from eight Gymnostoma species endemic to New Caledonia. Eur J Soil Biol 35:199-205

Gonin M, Gensous S, Lagrange A, Ducousso M, Amir H, Jourand P (2013) Rhizosphere bacteria of Costularia spp. from ultramafic soils in New Caledonia: diversity, tolerance to extreme edaphic conditions, and role in plant growth and mineral nutrition. Can J Microbiol 59:164-174

Grandcolas P, Murienne J, Robillard T, Desutter-Grandcolas L, Jourdan H, Guilbert E, Deharveng L (2008) New Caledonia: a very old Darwinian island? Philos Trans R Soc Lond Ser B Biol Sci 363:3309-3317

Guentas L, Gensous S, Cavaloc Y, Ducousso M, Amir H, De Georges de Ledenon B, Moulin L, Jourand P (2016) Burkholderia novacaledonica sp. nov. and B. ultramafica sp. nov. isolated from roots of Costularia spp. pioneer plants of ultramafic soils in New Caledonia. Syst Appl Microbiol 39:151-159. doi:10.1016/j.syapm.2016.03.008

Harrison S (1997) How natural habitat pathchiness affects the distribution of diversity in California sperpentine chaparral. Ecology 78:1898-1906

Harrison S, Inouye BD (2002) High beta diversity in the flora of Californian serpentine 'islands'. Biodivers Conserv 11:18691876

Harter DEV, Irl SDH, Seo B, Steinbauer MJ, Gillespie R, Triantis KA, Fernández-Palacios J-M, Beierkuhnlein C (2015) Impacts of global climate change on the floras of oceanic islands-projections, implications and current knowledge. Perspect Plant Ecol Evol Syst. doi:10.1016/ j.ppees.2015.01.003

Hequet V, Le Corre M (2010) Révision du catalogue des plantes introduites de H.S. MacKee (1994). IRD, Nouméa

Hery M, Nazaret S, Jaffré T, Normand P, Navarro E (2003) Adaptation to nickel spiking of bacterial communities in Neo-caledonian soils. Environ Microbiol 5:3-12 
Honnay O, Jacquemyn H (2006) Susceptibility of common and rare plant species to the genetic consequences of habitat fragmentation. Conserv Biol 21:823-831

Hopper SD, Gioia P (2004) The Southwest Australian Floristic Region: evolution and conservation of a global hot spot of biodiversity. Annu Rev Ecol Evol Syst 35:623-650. doi:10. 1146/annurev.ecolsys.35.112202.130201

Ibanez T, Hély C, Gaucherel C (2013) Sharp transitions in microclimatic conditions between savanna and forest in New Caledonia: insights into the vulnerability of forest edges to fire. Austral Ecol 38:680-687. doi:10.1111/aec.12015

Ibanez T, Munzinger J, Dagostini G, Hequet V, Rigault F, Jaffré T, Birnbaum P (2014) Structural and floristic characteristics of mixed rainforest in New Caledonia: new data from the New Caledonian Plant Inventory and Permanent Plot Network (NC-PIPPN). Appl Veg Sci 17:386-397. doi:10.1111/avsc. 12070

Iturralde RB (2001) The influence of ultramafic soils on plants in Cuba. S Afr J Sci 97

Jaffré T (1977a) Composition chimique élémentaire des tissus foliaires des espèces végétales colonisatrices des anciennes mines de nickel en Nouvelle-Calédonie. Cah ORSTOM, sér Biol XII, pp 323-330

Jaffré T (1977b) Accumulation du manganèse par des espèces associées aux terrains ultrabasiques de Nouvelle-Calédonie. C R Acad Sci Paris (D) 284:1573-1575

Jaffré T (1979) Accumulation du manganèse par les Protéacées de Nouvelle-Calédonie. C R Acad Sci Paris (D) 289:25-428

Jaffré T (1980) Etude écologique du peuplement végétal des sols dérivés de roches ultrabasiques en Nouvelle-Calédonie. Travaux et Document $n^{\circ} 124$, ORMSTOM, Paris. Available at: http://horizon.documentation.ird.fr/exl-doc/pleins_textes/ pleins_textes_6/Tra_d_cm/00393.pdf

Jaffré T (1992) Floristic and ecological diversity of the vegetation on ultramafic rocks in New Caledonia. In: Baker AJM, Proctor J, Reeves RD (eds) The vegetation of ultramafic (Serpentine) soils. Intercept Ltd, Andover

Jaffré T (1993) Relation between ecological diversity and floristic diversity in New Caledonia. Biodivers Lett 1:82-91

Jaffré T (1995) Distribution and Ecology of the Conifers of New Caledonia. In: Enright NJ, Hill RS (eds) Conifers of the Southern Hemisphere. Melbourne University Press, Australia

Jaffré T, L'Huillier L (2010) La végétation des roches ultramafiques ou terrains miniers. In: L'Huillier L, Jaffré T, Wulff A (eds) Mines et Environnement en NouvelleCalédonie : Les milieux sur substrats ultramafiques et leur restauration. Editions IAC, Nouméa

Jaffré T, Latham M (1974) Contribution à l'étude des relations solvégétation sur un massif de roches ultrabasiques de la côte Ouest de la Nouvelle-Calédonie : le Boulinda. Adansonia 14: 311-336

Jaffré T, Schmid M (1974) Accumulation du nickel par une Rubiaceae de Nouvelle-Calédonie, Psychotria douarrei (G. Beauvisage) Däniker. C R Acad Sci Paris (D) 278: $1727-1730$

Jaffré T, Veillon JM (1991) Etude floristique et structurale de deux forêts denses humides sur roches ultrabasiques en NouvelleCalédonie. Bull Mus Natl Hist Nat B Adansonia 4è(sér 12): 243-273

Jaffré T, Veillon JM (1995) Structural and floristic characteristics of a rain forest on schist in New Caledonia: a comparison with an ultramafic rain forest. Bull Mus Natl Hist Nat B Adansonia 4è(sér 17):201-226

Jaffré T, Brooks RR, Lee J, Reeves RD (1976) Sebertia acuminata, a hyperaccumulator of nickel from New Caledonia. Science 193:579-580

Jaffré T, Morat P, Veillon JM, MacKee HS (1987) Changements dans la végétation de la Nouvelle-Calédonie au cours du tertiaire : la végétation et la flore des roches ultrabasiques. Bull Mus Natl Hist Nat B Adansonia 4è(sér 9):365-391

Jaffré T, Gauthier D, Rigault F, McCoy SG (1994) Les Casuarinacées endémiques: Caractéristiques écologiques et nutritionnelles. Bois For Trop 242:31-43

Jaffré T, Bouchet P, Veillon JM (1998a) Threatened plants of New Caledonia: is the system of protected areas adequate? Biodivers Conserv 7:107-135

Jaffré T, Rigault F, Dagostini G (1998b) Impact des feux de brousse sur les maquis ligno-herbacés des roches ultramafiques de Nouvelle-Calédonie. Adansonia sér 3(20): 173-189

Jaffré T, Rigault F, Dagostini G, Fambart-Tinel J, Wulff A, Munzinger J (2009) Input of the different vegetation units to the richness and endemicity of the New Caledonian flora. In: Mery P (ed) Proceedings of the 11 th Pacific Science InterCongress, Tahiti, French Polynesia, 2-6 March, 2009. Honolulu HI : Pacific Science Association, Tahiti. http:// horizon.documentation.ird.fr/exl-doc/pleins_textes/divers1312/010060983.pdf

Jaffré T, Munzinger J, Lowry PP II (2010) Threats to the conifer species found on New Caledonia's ultramafic massifs and proposals for urgently needed measures to improve their protection. Biodivers Conserv 19:1485-1502. doi:10.1007/ s10531-010-9780-6

Jaffré T, Rigault F, Munzinger J (2012) La végétation. In: Bonvallot J, Gay J-C, Habert E (eds) Atlas de la NouvelleCalédonie. IRD-Congrès de la Nouvelle-Calédonie, Marseille-Nouméa

Jaffré T, Pillon Y, Thomine S, Merlot S (2013) The metal hyperaccumulators from New Caledonia can broaden our understanding of nickel accumulation in plants. Front Plant Sci 4:279

Jordan GJ, Dillon RA, Weston PH (2005) Solar radiation as a factor in the evolution of scleromorphic leaf anatomy in Proteaceae. Am J Bot 92:789-796

Jourand P, Ducousso M, Reid R, Majorel C, Richert C, Riss J, Lebrun M (2010) Nickel-tolerant ectomycorrhizal Pisolithus albus ultramafic ecotype isolated from nickel mines in New Caledonia strongly enhance growth of a host plant at toxic nickel concentrations. Tree Physiol 30:1311-1319

Jourand P, Hannibal L, Majorel C, Mengant S, Ducousso M, Lebrun M (2014) Ectomycorrhizal Pisolithus albus inoculation of Acacia spirorbis and Encalyptus globulus grown in ultramafic topsoil enhance plant growth and mineral nutrition while limits metal uptake. J Plant Physiol 171:164-172

Kay KM, Ward KL, Watt LR, Schemske DWS (2011) Plant speciation. In: Harrison S, Rajakaruma N (eds) Serpentine: the evolution and ecology of a model system. University of California Press, Los Angeles

Kazakou E, Dimitrakopulos PG, Baker AJM, Reeves RD, Trombis AY (2008) Hypotheses, mechanisms and trade-off of tolerance and adaptation to serpentine soils: from species ecosystems to ecosystems level. Biol Rev 83:495-508 
Kettle CJ, Hollingsworth PM, Jaffré T, Moran B, Ennos RA (2007) Identifying the early genetic consequences of habitat degradation in a highly threatened tropical conifer, Araucaria nemorosa Laubenfels. Mol Ecol 16:3581-3591

Kruckeberg AR (1954) The ecology of serpentine soils: III Pant species in relation to serpentine soils. Ecology 35:267-274

Kruckeberg AR (1984) California serpentine: flora, vegetation, geology, soils and management problems. University of California Press, Berkeley

Kruckeberg AR (1991) An essay: geoedaphics and island biogeography for vascular plants. Aliso 13:225-238

Kruckeberg AR (2002) Geology and plant life: the effects of landforms and rock type on plants. University of Washington Press, Seattle

L'Huillier L (1994) Biodisponibilité du nickel dans les sols ferrallitiques de Nouvelle-Calédonie. Effets sur le développement et la physiologie du maïs. University of Montpellier II, France

L'Huillier L, Edighoffer S (1996) Extractability of nickel and its concentration in cultivated plants in Ni rich ultramafic soils of New Caledonia. Plant Soil 186:255-264

L'Huillier L, Jaffré T, Wulff A (2010) Mines et Environnement en Nouvelle-Calédonie : Les milieux sur substrats ultramafiques et leur restauration. Editions IAC, Nouméa

Lambers H, Raven JA, Shaver GR, Smith SE (2008) Plant nutrient-acquisition strategies change with soil age. Trends Ecol Evol 23:95-103

Lambers H, Shane MW, Laliberté E, Swarts N, Teste F, Zemunik G (2014) Plant mineral nutration. In: H Lambers (ed) Plant Life on the Sandplains in Southwest Australia, a global biodiversity hotspot-Kwongan matters. University of Western Australia Press

Lambers H, Hayes PE, Laliberte E, Oliveira RS, Turner BL (2015) Leaf manganese accumulation and phosphorus-acquisition efficiency. Trends Plant Sci 20:83-90. doi:10.1016/j.tplants. 2014.10.007

Lamont BB, Groom PK, Cowling RM (2002) High leaf mass per area of related species assemblages may reflect low rainfall and carbon isotope discrimination rather than low phosphorus and nitrogen concentrations. Funct Ecol 16:403-412

Latham M (1975) Les sols d'un massif de roches ultrabasiques de la Côte ouest de Nouvelle-Calédonie. Le Boulinda. Cahiers ORSTOM, sér Pedol XIII, pp 159-172

Latham M (1981) Aptitude culturales et forestières des sols. Planche 28. Atlas de la Nouvelle-Calédonie. ORSTOM, Paris

Latham M, Quantin C, Aubert G (1978) Etude des sols de la Nouvelle-Calédonie. Notice explicative no 78 ORSTOM, Paris, France

Lee WG (1992) New Zealand ultramafics. In: Robert BA, Proctor J (eds) The ecology of areas with serpentinized rocks a world view. Kluwer Academic Press, Dordrecht

Losfeld G, L'Huillier L, Fogliani B, McCoy SG, Grison C, Jaffré T (2015) Leaf-age and soil-plant relationships: key factors for reporting trace-elements hyperaccumulation by plants and design applications. Environ Sci Pollut Res 22:5620-5632

Lowry II PP (1998) Diversity, endemism, and extinction in the flora of New Caledonia: a review. In: Peng C-I, Lowry II PP (eds) Rare, threatened, and endangered floras of Asia and the Pacific. Institute of Botany, Academica Sinica, Monogr. Ser. No. 16, Taipei
McCoy SG, Jaffré T, Rigault F, Ash JE (1999) Fire and succession in the ultramafic maquis of New Caledonia. J Biogeogr 26: 579-594

Mengoni A, Baker AJM, Bazzicalupo M, Reeves RD, Adigüzel N, Chianni E, Galardi F, Gabbrielli R, Gonnelli C (2003) Evolutionary dynamics of nickel hyperaccumulation in Alyssum revealed by ITS nrDNA analysis. New Phytol 159: 691-699

Merlot S, Hannibal L, Martin S, Martinelli L, Amir H, Lebrun M, Thomine S (2014) The metal transporter PgIREG1 from the hyperaccumulator Psychotria gabriellae is a candidate gene for nickel tolerance and accumulation. J Exp Bot 65:1551-1564

Meyer J-Y, Loope LL, Sheppard A, Munzinger J, Jaffré T (2006) Les plantes envahissantes et potentiellement envahissantes dans l'archipel néo-calédonien : première évaluation et recommandations de gestion. In: Beauvais M-L, Coléno A, Jourdan H (eds) Les espèces envahissantes dans l'archipel néo-calédonien. Expertise collégiale : IRD, Paris

Morat P (1993) The terrestrial biota of New Caledonia. Biodivers Lett 1:69-71

Morat P, Jaffré T, Veillon JM, MacKee HS (1986) Affinités floristiques et considérations sur l'origine des maquis miniers de la Nouvelle-Calédonie. Bull Mus Natl Hist Nat B Adansonia 4è(sér 8):133-182

Morat P, Jaffré T, Veillon JM (1994) Richesse et affinités floristiques de la Nouvelle-Calédonie : conséquence directe de son histoire géologique. Mém Soc Biogéogr 4:111-123

Morat P, Jaffré T, Veillon JM (2001) The flora of New Caledonia's calcareous substrates. Adansonia sér 3(23):109-127

Morat P, Jaffré T, Tronchet F, Munzinger J, Pillon Y, Veillon JM, Chalopin M (2012) Le référentiel taxonomique Florical et les caractéristiques de la flore vasculaire indigène de la Nouvelle-Calédonie. Adansonia sér 3(34):177-219. doi:10. 5252/a2012n2a1

Mouly A, Jeanson M (2015) Specialization to ultramafic substrates and narrow endemism of Cyclophyllum (Rubiaceae) in New Caledonia: contribution of novel species to the understanding of these singular patterns. Acta Bot Gallica 162: 173-189. doi:10.1080/12538078.2015.1062799

Murienne J (2009) New Caledonia: biology. In: Gillespie R, Clague D (eds) Encyclopedia of islands. University of California Press, Berkeley

Myers N, Mittermeier RA, Mittermeier CG, da Fonseca GAB, Kent J (2000) Biodiversity hotspots for conservation priorities. Nature 403:853-858

Nasi R, Jaffré T, Sarrailh JM (2002) Les forêts de montagnes de Nouvelle-Calédonie. Bois For Trop 274:5-17

Navarro I, Jaffré T, Gauthier D, Gourbiere F, Rinaudo G, Simonet P (1999) Distribution of Gymnostoma spp. microsymbiotic Frankia strains in New Caledonia is related to soil type and host-plant species. Mol Ecol 8:1781-1788

O’Dell RE, Rajakaruna N (2011) Intraspecific variation, adaptation, and evolution. In: Harrison SP, Rajakaruna N (eds) Serpentine: the evolution and ecology of a model system. Univ. of California Press, Berkeley

Pelletier B (2006) Geology of the New Caledonia region and its implications for the study of the New Caledonian biodiversity. In: Payri C, Richer de Forges B (eds) Compendium of marines species from New Caledonia. Doc. Sci. Tech. IRD, II 7, Nouméa 
Perrier N, Colin F, Jaffré T, Ambroisi JR, Ballero JP (2004) Nickel speciation in Sebertia acuminata, a plant growing on a laterite soil in New Caledonia. C R Geosci 333: $567-577$

Perrier N, Amir H, Colin F (2006) Occurrence of mycorrhizal symbioses in the metal-rich lateritic soils of the Koniambo Massif New Caledonia. Mycorrhiza 16:449-458

Perry GLW, Enright NJ (2002) Spatial modelling of landscape composition and pattern in a maquis-forest complex, Mont Do, New Caledonia. Ecol Model 152:279-302

Pillon Y (2012) Time and tempo of diversification in the flora of New Caledonia. Bot J Linn Soc 170:288-298. doi:10.1111/j. 1095-8339.2012.01274.x

Pillon Y, Hopkins HC, Bradford J (2008) Two new species of Cunonia (Cunoniaceae) from New Caledonia. Kew Bull 63: 419-431

Pillon Y, Munzinger J, Amir H, Hopkins HC, Chase MW (2009) Reticulate evolution on a mosaic of soils: diversification of the New Caledonian endemic genus Codia (Cunoniaceae). Mol Ecol 18:2263-2275

Pillon Y, Munzinger J, Amir H, Lebrun M (2010) Ultramafic soils and species sorting in the flora of New Caledonia. J Ecol 98: 1108-1116. doi:10.1111/j.1365-2745.2010.01689.x

Pillon Y, Hopkins HCF, Rigault F, Jaffré T, Stacy EA (2014) Cryptic adaptive radiation in tropical forest trees in New Caledonia. New Phytol 202:521-530. doi:10.1111/nph. 12677

Pintaud JC, Jaffré T (2001) Pattern of diversification of Palms on ultramafic rocks in New Caledonia. S Afr J Sci 97:548-550

Pintaud J-C, Jaffré T, Puig H (2001) Chorology of New Caledonian palms and possible evidence of Pleistocene rain forest refugia. C R Acad Sci III- Vie 324:453-463

Pouteau R, Trueba S, Feild TS, Isnard S (2015) New Caledonia: a Pleistocene refugium for rainforest lineages of relict angiosperms. J Biogeogr 42:2062-2077

Proctor J (2003) Vegetation and soil and plant chemistry on ultramafic rocks in the tropical Far East. Perspect Plant Ecol Evol Syst 6:105-124

Rajakaruma N, Boyd RS (2008) The edaphic factor. Encyclopedia of ecology. Elsevier

Rajakaruna N (2004) The edaphic factor in the origin of plant species. Int Geol Rev 46:471-478

Rajakaruna N, Baker AJM (2004) Serpentine: a model habitat for botanical research in Sri Lanka. Cey J Sci (Biol Sci) 32:1-19

Read J, Jaffré T, Hope GS, Godrie E, Veillon JM (2000) Structural and floristic characteristics of some monodominant and adjacent mixed rainforests in New Caledonia. J Biogeogr 27: 233-250

Read J, Ferris JM, Jaffré T (2002) The foliar mineral content of Nothofagus species on ultramafic soils in New Caledonia and non-ultramafic soils in Papua New Guinea. Aust J Bot 50: 607-617

Read J, Jaffré T, Ferris JM, McCoy SG, Hope GS (2006a) Does soil determine the boundaries of monodominant rain forest with adjacent mixed rain forest and maquis on ultramafic soils in New Caledonia? J Biogeogr 33:1055-1065

Read J, Sanson G, de Garine-Wichatitsky M, Jaffré T (2006b) Sclerophylly in two contrasting tropical environments : low nutrients vs low rainfall. Am J Bot 93:1601-1614

Read J, Lamont BB, Sanson G, de Garine-Wichatitsky M, Jaffré T (2007) Is sclerophylly the same phenomenon in shrublands in contrasting environments? Kwongan in Western Australia and maquis in New Caledonia. In: Rokich D, WardellJohnson G, Yates C, Stevens J, Dixon K, McLellan R, Moss G (eds) MEDECOS XI 2007 Conference, Kings Park and Botanic Garden, Perth, Australia

Read J, Sanson G, Burd M, Jaffré T (2008) Mass flowering and parental death in the regeneration of Cerberiopis candelabra (Apocynaceae), a long-lived monocarpic tree in New Caledonia. Am J Bot 95:558-567

Reddell P, Bowen GD, Robson AD (1986) Nodulation of Casuarinaceae in relation to host species and soil properties. Aust J Bot 34:435-444

Reeves RD, Baker AJM, Borhidi A, Berazain R (1996) Nickel accumulating plants from the ancient serpentine soils of Cuba. New Phytol 133:217-224

Reeves RD, Baker AJM, Borhidi A, Berazain R (1999) Nickel hyperaccumulation in the serpentine flora of Cuba. Ann Bot 83:29-38

Richardson JE, Weitz FM, Fay MF, Cronk QCB, Linder HP, Reeves G, Chase MW (2001) Rapid and recent origin of species richness in the Cape flora of South Africa. Nature 412:181-183

Rigg L, Enright NJ, Jaffré T, Perry GLW (2010) Contrasting population dynamics of the endemic New Caledonian conifer, Araucaria laubenfelsii, in maquis and rainforest. Biotropica 42:479-487

Safford HD, Viers JH, Harrison SP (2005) Serpentine endemism in the California flora: a database of serpentine affinity. Madrono 52(4):22-257

Schmid M (1981) Fleurs et plantes de Nouvelle-Calédonie. Editions du Pacifique, Nouméa

Schmid M (1982) Endémisme et spéciation en NouvelleCalédonie. C R Soc Biogéogr 58:52-60

Schnitzler J, Barraclough TG, Boatwright JS, Goldblatt P, Manning JC, Powell MP, Rebelo T, Savolainen V (2011) Causes of plant diversification in the Cape biodiversity hotspot of South Africa. Syst Biol 60:343-357. doi:10. 1093/sysbio/syr006

Shane MW, Cawthray GR, Cramer MD, Kuo J, Lambers H (2006) Specialized 'dauciform' roots of Cyperaceae are structurally distinct, but functionally analogous with 'cluster'roots. Plant Cell Environ 29:1989-1999

Smith SE, Read J (2008) Mycorrhizal symbiosis. Elsevier

Stevanović V, Kit T, Iatrou G (2003) Distribution of the endemic Balkan flora on serpentine I. Obligate serpentine endemics. Plant Syst Evol 242:149-170

Swenson U, Lowry PP II, Munzinger J, Rydin C, Bartish IV (2008) Phylogeny and generic limits in the Niemeyera complex of New Caledonian Sapotaceae: evidence of multiple origins of the anisomerous flower. Mol Phylogenet Evol 49: 909-929. doi:10.1016/j.ympev.2008.09.022

Taylor S, Kumar L (2016) Global climate change impacts on pacific islands terrestrial biodiversity: a review. Trop Conserv Sci 9:203-223

Thorne RF (1965) Floristic relationships of New Caledonia. Stud Nat Hist Iowa Univ 20:1-14

Trescases JJ (1975) L'évolution geochimique supergène des roches ultrabasiques en zone tropicale. Formation des gisements nickèlifères de Nouvelle-Calédonie. Mémoire ORSTOM, pp 1-284 
van der Ent A, Baker AJM, Reeves RD, Pollard AJ, Schat H (2013) Hyperaccumulators of metal and metalloid trace elements: facts and fiction. Plant Soil 362:319-334

van der Ent A, Repin R, Sugau J, Wong KM (2014) The ultramafic flora of Sabah. An introduction to the plant diversity on ultramafic soils. Natural History Publication, Borneo

van der Ent A, Jaffré T, L'Huillier L, Gibson N, Reeves RD (2015a) The flora of ultramafic soils in the AustraliaPacific Region: state of knowledge and research priorities. Aust J Bot 63:173-190. doi:10.1071/BT15038

van der Ent A, Repin R, Sugau J, Wong KM (2015b) Plant diversity and ecology of ultramafic outcrops in Sabah (Malaysia). Aust J Bot 63:204-215. doi:10.1071/BT14214

van der Ent A, Echevarria G, Tibbett M (2016) Delimiting soil chemistry thresholds for nickel hyperaccumulator plants in Sabah (Malaysia). Chemoecology 26:67-82. doi:10.1007/ s00049-016-0209-x
Virot R (1956) La végétation canaque. Mém Mus Natl Hist Nat Ser B Bot 7:1-400

Walker RB (1954) The ecology of serpentine soils. II Factor affecting plant growth on serpentine soils. Ecology 35:259-266

Whittaker RH (1954) The ecology of serpentine soils. IV The vegetation response to serpentine soils. Ecology $35: 275-288$

Wulff A, L'Huillier L, Véa C, Jaffré T (2010) Espèces indigènes utilisables en revégétalisation. In: L'Huillier L, Jaffré T, Wulff A (eds) Mines et Environnement en NouvelleCalédonie : Les milieux sur substrats ultramafiques et leur restauration. IAC, Nouméa

Wulff AS, Hollingsworth PM, Ahrends A, Jaffré T, Veillon JM, L'Huillier L, Fogliani B (2013) Conservation priorities in a biodiversity hotspot: analysis of narrow endemic plant species in New Caledonia. Plos One 8, e73371. doi:10.1371/ journal.pone.0073371 